\title{
Wildfire volunteering and community disaster resilience in New Zealand: institutional change in a dynamic rural social-ecological setting
}

\author{
Andrea Grant $^{1}$ and E. R. (Lisa) Langer ${ }^{1}$
}

\begin{abstract}
Wildfire is a major environmental hazard, yet the social and institutional aspects of wildfire risk management have received limited attention in the literature. Considering future climate change, changing demographics, and the increased demands on fire services more generally, there is an urgent need to better understand the significance of volunteers in emergency management. Volunteering brings together community actors and formal institutions in responding to natural hazards including wildfires. In this paper, we use systemic co-inquiry with volunteer leaders to better understand how to integrate formal and informal volunteers by addressing how resilience is being enacted and what opportunities exist for building community resilience. We examine practices of transitioning from past norms of volunteering to create new institutions for supporting community resilience to wildfires. Findings demonstrate the need for the emergency management sector to promote community resilience through the support of informal volunteers and move beyond traditional representations of rural fire brigade volunteers' roles as firefighters. Vulnerabilities at different organizational scales, community, brigade, and regional, limit existing arrangements for wildfire volunteering, and highlight the need to adapt to changing contexts. Opportunities for building community resilience are identified, including supporting non-firefighting roles for brigade volunteers; aligning with spontaneous volunteers for enhancing rural community disaster preparedness; and outreach to support preparedness activities in isolated and remote communities. Building on the direct experiences of our participants, we articulate the importance of institutional reflexivity involving localized reflection on volunteer organization as a vehicle for change toward more resilient wildfire futures.
\end{abstract}

Key Words: institutional reflexivity; learning systems; natural hazards; volunteer leaders; wildfire resilience

\section{INTRODUCTION}

Wildfire is a major environmental hazard with significant impacts on people, property, and ecosystems around the world (Paton et al. 2015, Tedim et al. 2016). The effects of climate change are increasing these risks with implications for communities, infrastructure, and well-being (Moritz et al. 2014, McWethy et al. 2019). Consequently, there is an urgent need to better understand the social and institutional aspects of wildfire risk management that remain underexplored relative to the engineering and technical features of wildfire risk. Volunteering is both a social and institutional aspect of wildfire and disaster response that is increasingly important to community resilience (McLennan and Birch 2005, McLennan et al. 2016).

A broad literature on volunteering exists exploring motivations, recruitment, and retention issues or aspects of these (HaskiLeventhal and Cnaan 2009, Hong et al. 2009, Hustinx et al. 2010, Livi et al. 2020). We do not replicate that here, however note that the adaptiveness of volunteer organizations to changing circumstances has received limited attention in this literature. Disaster and emergency response volunteering is a special case of volunteering in which there is an emerging interest in the role of informal volunteers including spontaneous, casual, and episodic volunteers (Saaroni 2015, Harris et al. 2016, McLennan et al. 2016). We add to the literature on disaster and emergency response volunteers through a multi-sited case study of formal and informal volunteering and wildfire management in Aotearoa New Zealand (New Zealand). For the purposes of this paper, formal volunteers are defined as those that obtain membership of an organization and receive training and liability protections, while informal volunteers are those that do not meet such criteria (Grant and Langer 2019).
Volunteering brings together community actors and formal institutions in responding to natural hazards including wildfires (Cowlishaw et al. 2008, Haski-Leventhal and McLeigh 2009). It provides an important service and function where state-based programs or market developments do not meet the needs of vulnerable communities (Lough 2018). Research on volunteering intersects many topics related to community resilience including the elderly, young people, refugee communities, environmental conservation, and disasters (Morrow-Howell et al. 2011, Woodier 2011, Rast et al. 2019, Miller 2020). In the disaster space, there is growing emphasis on the need to better understand the demands and pressures on formal volunteering traditions, e.g., through emergency services (Whittaker et al. 2015, McLennan et al. 2016). For example, some have shown an emphasis on legal liability (authorization) and formal cultures of volunteer resourcing (legitimacy) as constraints for building community resilience (Whittaker et al. 2015, McLennan et al. 2020). In other cases, local community groups hold primary responsibility for disaster resilience (Hayward 2013, Blackman et al. 2017), despite capacity and resourcing limitations (Halliday et al. 2013). More broadly, formal volunteering is said to be in a state of transition where top-down command and control approaches are giving way to more locally empowered volunteers (Lough 2018) that can be more acutely aware of community needs and vulnerabilities (Blackman et al. 2017). Although such people-centered, participatory approaches have resourcing limitations, they do offer a means for leading transformational approaches to building community resilience from the bottom up (Halliday et al. 2013, Blackman et al. 2017, Lough 2018). Local points of reference can help centralized organizations develop a self-critical ability and validate institutional reflexivity ${ }^{[1]}$ (Boström et al. 2017), as a means for understanding change and environmental pressure on 
volunteers. Therefore, local initiatives need not be a replacement for more bureaucratic approaches but seek greater opportunities for coordination and partnership.

Our inquiry starts from a critical perspective of community resilience (Mulligan et al. 2016). We build upon the literature on social-ecological resilience (Folke 2006, Berkes and Ross 2013, Chaffin and Gunderson 2016) through a socially based methodological framework that can support understanding of how resilience is generated, focusing on the agency of formal and informal volunteer leaders, for addressing vulnerabilities in differently situated communities.

The paper begins with a brief review of the literature on community resilience and hazards, focusing in on resilience and wildfire management. The research setting and methods are introduced and our development of a systemic co-inquiry (Foster et al. 2019) conducted with research participants is described. Findings are presented in terms of the scale of organization and leadership characteristics of our key participants, vulnerabilities they identify, and insights gained from their experiences and practice. In the discussion, attention is paid to the need for institutional reflexivity at different sites and scales of disaster volunteering, through systemic co-inquiry between researchers and people in practical settings of resilience building, to better understand and facilitate social learning (Collins and Ison 2009, Ison et al. 2015). We reflect on the implications of three volunteer initiatives across different scales of organization from community to brigade to region, documenting the perspectives and activities of key individuals and their desire to build the resilience of others.

\section{COMMUNITY RESILIENCE IN HAZARDS SETTINGS}

Community resilience is the focus of recent research, policy, and practice across diverse fields and problems (Janssen and Ostrom 2006, Gidley et al. 2009, Allen et al. 2014, Saunders and Becker 2015, Graham et al. 2016). For hazards settings, limitations have been noted from legislations that frame and resource centralized responses to hazard events rather than capacities to address vulnerabilities within communities, empowering local assessments and actors within such settings to narrate and support the development of resilience (Larsen et al. 2011, Manyena et al. 2013, Henly-Shepard et al. 2015). Some have indicated that governance mechanisms for building community resilience to environmental hazards require the active involvement of stakeholders and more dispersed approaches to understand vulnerability, construct resilience measures, and learn from experience (Adger 2006, Barnett et al. 2008, Aldunce et al. 2016). In New Zealand this is most evident in the recent National Disaster Resilience Strategy, an all of government strategy for a coherent, joined-up approach that connects across organizational mandates, and the primary mechanism for New Zealand to realize its obligations under the Sendai Framework for Disaster Risk Reduction (UNISDR 2015, MCDEM 2019). In the context of New Zealand's multi-hazard environment, Spector et al. (2019) adopted the United Nation's definition of resilience as: "the ability of a system, community or society exposed to hazards to resist, absorb, accommodate to and recover from the effects of a hazard in a timely and efficient manner, including through the preservation and restoration of its essential basic structures and functions" (UNISDR 2009:24). However, this has limitations for resilience where underlying social structures may prevent the ability of communities to prepare and develop individual or collective self-reliance in times of disasters. Systemic changes to prior states, i.e., organizational capacities and institutional responses built into historical practices, may be needed (Ison 2019), as we learn more and realize the limitations of past institutions for our current circumstances, illustrated by Figure 1 .

Fig. 1. Institutional reflexivity as an outcome of new experiences and new judgements (based on Vickers 1965 appreciative system; see also Checkland and Casar 1986).

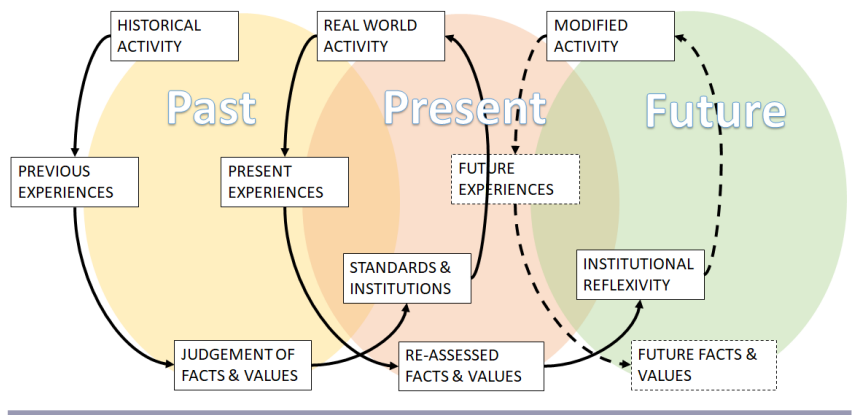

The Sendai Framework also notes the need to move beyond thinking about resilience as "bouncing back" to accommodate past inequalities and inefficiencies to create something better (UNISDR 2015), so too the Intergovernmental Panel on Climate Change 2012 report on disaster vulnerability (Lavell et al. 2012). One poorly recognized problem with defining resilience is that multiple measures of a system's performance may be required ( $\mathrm{R}$. Ison, personal communication). It is not only in the domain of environmental hazard that we are required to adapt but areas of social organization where vulnerabilities are created. Resilience in the literature around ecological disturbances has gone some way to introduce ideas of social resilience into social-ecological sustainability (Folke 2006, Berkes and Ross 2013), but authors tend to focus on dynamic coupling rather than interpretive dimensions (Stojanovic et al. 2016). In resource management literature there are concerns about mismatches between social and ecological processes (Garmestani and Benson 2013), especially where management actions at one hierarchical level are incommensurate with those at another level (Cumming et al. 2006 , Cumming 2013). The flexibility of social organization that underpins effective adaptation to environmental changes (Wittmayer et al. 2014, Lawrence et al. 2015, Sharpe et al. 2016), e.g., those arising from climate change, and to support coevolution of social and ecological responses (Colvin et al. 2014, Ison 2016a, Ison 2019) at multiple scales of vulnerability, needs to be understood.

\section{Resilience and wildfire management}

From a wildfire perspective, McWethy et al. (2019) noted the need to understand both social and biophysical landscape contexts to identify strategies that can more effectively support sustainable coexistence with wildfire (see also Paveglio et al. 2010). They argued that adaptive and transformative resilience actions will depend on context including (i) human exposure and vulnerability, (ii) wildfire severity and human impacts, and (iii) changes in fire activities compared with historical experiences (see Pearce 2018, Baillie and Bayne 2019). However, a defining feature of human agency - the ability to mobilize or reflect on the 
vulnerability of oneself or others as a catalyst for action or realizing change (Hayward 2013, Sinclair et al. 2017) - is missing. Volunteers represent an archetype of such human agency and provide a suitably rich case study for exploring how aspects of vulnerability are recognized and resilience built.

In many jurisdictions including New Zealand, rapidly changing environmental conditions driven by climate change and periurban expansion are changing the context for wildfire exposure (Brenkert-Smith et al. 2012, De Groot and Flannigan 2014). Although the biophysical risks are recognized (Smith et al. 2016, Pearce 2018), initiatives for better understanding areas of vulnerability and response capacities need revision (Jakes et al. 2010, Paveglio et al. 2010). Higher fire danger associated with hotter and drier weather conditions (Moritz et al. 2014) and increased flammability of forested and agricultural landscapes puts rural areas at increasing risk (Baillie and Bayne 2019, Watt et al. 2019). New populations migrating to areas such as in urbanrural fringes (Prior and Eriksen 2013, Langer and Wegner 2018), and changing populations in remote areas (Stephens et al. 2009, Cochrane and Maré 2017) increases the vulnerability and exposure to wildfire risk. The protection of communities based on traditional community ties and liaisons may be a limiting factor for this changing context (Skutsch and Turnhout 2018). Yet the way we define community resilience and use the term in policy discourse gives little guidance for the translation of resilience into practice (Mulligan et al. 2016, Wither et al. 2021). We need to better understand the diverse and dynamic ways different community scales, networks, and power relations influence resilience (Vallance and Carlton 2015, Graham et al. 2016); clarify differences between top-down and bottom-up approaches to disaster resilience (Mamula-Seadon and McLean 2015); and recognize the centrality of human agency and deliberation (Coulthard 2012, Foster et al. 2019), to enable organizational change in response to changing (sometimes rapidly) social and ecological environments (Westley et al. 2013, Milkoreit et al. 2015).

\section{RESEARCH SETTING AND METHODS}

New Zealand is a small developed bi-cultural country established through treaty with its indigenous Māori population in the southwest Pacific comprising two large main islands (North and South) and several smaller ones. It relies heavily on primary industries for economic security with over $50 \%$ of exports earnings coming from the sector including wine, sheep, dairy products, timber, and with a growing horticultural industry (NZT 2016, KPMG 2018), albeit through contested and resisted forms of colonial development (Mutu 2019), and a growing recognition of the Māori economy (DFAT 2017). A significantly large marine environment also contributes to the national gross domestic product (NZT 2016). New Zealand is exposed to numerous natural hazards including earthquake, volcano, and tsunami as well as weather related hazards such as high impact events including winds, storms, flooding, and drought increasing in frequency and intensity because of climate change (National Emergency Management Agency 2019). The South Island has had its share of these, with major earthquakes in 2010-2011 in the city of Christchurch leaving a devastated city and 185 lives lost (Potter et al. 2015). More recent hazard events with the 2016 Kaikōura earthquake isolating rural and coastal communities for several weeks (Cradock-Henry et al. 2018), extreme fires in Port Hills surrounding Christchurch in the urban-rural fringe in 2017
(Pearce 2018), and 2019 Pigeon Valley fires near Nelson at the top of the South Island resulting in the reported evacuation of 2500-3000 people (RadioNZ 2019) have also had widespread adverse impacts.

\section{Wildfire management in New Zealand}

Nationally, the recently formed Fire and Emergency New Zealand (FENZ) is the centralized organization responsible for prevention, response, and suppression of fires. In addition to FENZ, there are other organizations aligned with rural fire service provision (although these are no longer formal fire authorities under the new FENZ structure), including New Zealand Forest Owners (NZFOA) and the Farm Forestry Association, Department of Conservation, and some local governments, with an active interest in policy discussion and legislation (NZFOA 2018), preparedness and response (Pearce et al. 2008). Volunteer rural fire brigades associated with the former Rural Fire Authority (RFA) also play a key role in fire suppression activities, and have recently been united with urban paid and volunteer brigades under FENZ (FENZ 2017). Across its rural and urban firefighting brigades, FENZ employs approximately 1810 career firefighters, 982 management and support personnel, and 11,801 volunteers (FENZ 2019a).

Volunteering is fundamental to enhancing community resilience in New Zealand's multi-hazard environment. Since their inception under the Forest and Rural Fires Act 1947, volunteer rural fire brigades have provided more than a fire service, also responding to road accidents, natural hazards, and other medical emergencies, educating on and ensuring safe use of fire, and protecting their communities from wildfires (Ethos Consulting 2017, FENZ 2018). Rural brigades have primarily been supported for their firefighting roles with a focus on fire related equipment and training (FENZ 2018). Today the setting for rural fire brigades in New Zealand involves the following:

- increasingly complex emergency response with hotter, drier conditions increasing the wildfire risk and wildland-urban fringe housing development (Langer and Wegner 2018, Pearce 2018);

- diminishing community base or one less inclined to formally volunteer with changes in local employment opportunity and work and family pressures (Alkema et al. 2013); and

- historically changing environmental and social conditions in rural regions, including the expansion of global interests in agriculture and the increased scale of farming and attendant operational requirements (Le Heron 1991, Klinge 2021).

To gain insight into the practical experiences of those working at the frontline of community wildfire resilience, and to understand the pressures and constraints on informal and formal aspects of wildfire volunteering, we focused on the initiatives of people in different organizational settings. Formal volunteers in our case study are those who receive training and liability protections (Grant and Langer 2019) from FENZ through membership of rural or urban fire brigades. Casual, spontaneous, or episodic volunteers including those that provide family or support roles for others, who might be more vulnerable or involved in formal disaster volunteering roles, are examples of informal volunteers (Whittaker et al. 2015). Rural brigades provide an important 
network and bridge between formal response organizations and local communities in New Zealand and elsewhere (McGee and Russell 2003).

\section{Research methodology}

Following Foster et al. (2019), we combined two interpretive research methods of systemic inquiry (Ison 2010) and co-inquiry (Heron 1996, Heron and Reason 1997). Systemic inquiry is a process of research that first defines a human activity system by exploring its key elements through direct connection of the researcher with the research setting or context. Co-inquiry is a complementary method that engages research participants in the research process to ensure insight about the context is grounded in participants' perspectives. Systemic co-inquiry is a mode of investigation or research with participants that is open to changing situations, pursing new directions, as a result of learning and testing new areas of understanding. It can result in engaging with new theoretical and methodological frameworks that come out of shared or joint learning and appreciating other people's perspectives (Foster et al. 2016).

The need to address increasingly complex problems, such as disaster management, has prompted growing application of multi-, inter- and transdisciplinary approaches (Brown et al. 2010, Curtin and Parker 2014) and systems thinking (Ison 2017) to move from observation based research to facilitating systems change. Systems thinking refers to a set of methodologies and related tools for dealing with complexity, ambiguity, diverse mental models, and problem framing (Ison 2010). Thinking in systems draws attention to the whole system, as an effect of the interactions between its component parts that cannot be known by looking at the parts independently. Systemic inquiry provides a basis for exploring change and complexity, by focusing on feedbacks between differently situated perspectives and what insights they bring to how we understand problems or problem framing (Ison 2010).

Co-inquiry is a methodological approach focused on inquiry "with" rather than "on" research subjects (Heron 1996), typically used in professional practice settings by nursing (health) and teaching (education) professionals (e.g., Kasl and Yorks 2002, Jenkins 2007). In general, it brings together a group or groups of people with researchers to examine a problem they are trying to address such as improving teaching and learning performance (Werder et al. 2016, Glasswell et al. 2016). Co-inquirers work collectively to define the problem and articulate solutions that help them reflect on the limitations of their practice and understanding for achieving desired outcomes.

Systemic co-inquiry can be enacted in different ways depending on the context and the co-inquiry participants (see Appendix for a fuller explanation of systemic co-inquiry). It brings people involved in a problematic situation together to define the problem and articulate solutions using systems thinking and approaches (Foster et al. 2016) in a constructive way to facilitate change. In this case we situated ourselves as researchers, through ethnographic approaches, into the worlds of our participants as co-inquirers. From that point we built our systemic co-inquiry from the inside out. Rather than relying on our expert knowledge, we followed our participants and directly questioned them about their experiences to ensure we understood their perspectives of vulnerability to design potential interventions with their insights on how community resilience was practiced or not.
Our methodology drew upon the extensive experience of our second author in researching social aspects of rural fire through over a decade of research case studies in New Zealand. We also conducted a comprehensive literature review reflecting on practical changes in wildfire resilience activities (Grant and Langer 2019). From here we worked with the perspectives of differently situated volunteer actor-leaders within New Zealand to help understand institutional limitations for responding to vulnerabilities of wildfire exposed communities. Our engagement was designed to create the basis for social learning with our volunteer actor-leaders.

Developing and enacting a systemic co-inquiry for enhancing rural community wildfire resilience with our research participants comprised four steps (Box 1, Fig. 2). There was a need to become familiar with the setting, to plan for research that integrated with what participants were already doing, and to link up research questions with their setting. Following these initial steps, a framework for co-inquiry addressing the central question was developed during interactions with research participants. Our approach was to embed problem framing in our participants experiences, through steps $1-4$, to ensure our systemic co-inquiry emerged directly from their experiences. The process was designed to support emergent, contextual, and reflexive learning between the key actors to identify specific outcomes and necessary conditions to enable systemic co-inquiry (Ison and Blackmore 2014, Ison 2016b, Allan et al. 2020). We focus on the outcomes of these four steps, guided by our central question emerging from the context of our inquiry: how is resilience being enacted and what opportunities exist for building community resilience to wildfires?

Box 1: A framework ${ }^{[2]}$ and guide for co-inquiry leading to systemic co-inquiry (Fig. 2).

\section{Steps}

1. Get familiar with the setting;

2. Plan for research that integrates / "fits in with" what people are already doing/finding out;

3. Link up research questions with the setting, i.e., that fits (Step 2);

4. Develop a framework for co-inquiry that addresses an overarching question/area of interest that could be relevant for wider application.

Outcomes

Inquiry emerges out of a real world setting and is not imposed.

Learning is applicable to the context people are working in.

Knowledge is gained that can guide future learning opportunities.

Necessary conditions

Conditions for monitoring and evaluating change/s need to be developed.

Critical engagement/capacity for self-critique, reflexivity, needs to be developed for an effective learning system (Ison 2019). 
Fig. 2. Steps for developing co-inquiry with feedback loops, leading to systemic co-inquiry.

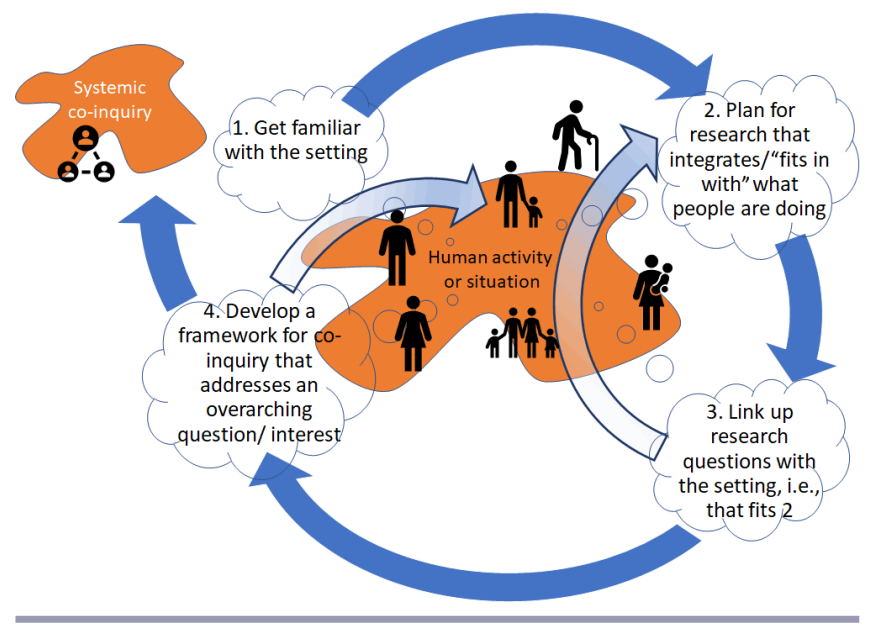

We focused on three sites of "resilience practice" where we found our participants played a role in leading volunteers within the rural multi-hazard environment of Marlborough/ North Canterbury (Fig. 3). These initiatives were the work of local leaders (referred to as "actor-leaders" in this paper) operating at brigade, community, and regional scales. As owners of these initiatives, our actor-leaders recognized and worked with areas of vulnerability in their volunteer and beneficiary communities. We met each of our actor-leaders in different circumstances while scoping a research project looking at ways to enhance community wildfire resilience. Prior to meeting we were interested in and looking to explore wildfire volunteering possibilities beyond traditional firefighter roles. We identified our actor-leaders as people demonstrating agency beyond the boundaries of existing institutions for emergency management within a geographic area exposed to multiple hazards. The first actor-leader was a spontaneous informal volunteer and business woman who responded to community (Community A) need following the Kaikōura earthquakes. The second actor-leader was a volunteering member of a satellite town (Community B) "composite" fire brigade (from an urban-rural fringe setting with both built and natural environment firefighting skills), attempting to introduce five-year succession planning to their brigade; and the third actor-leader was an emergency services regional officer in an employed position providing volunteer brigade support and organizational leadership across the region, including communities in remote areas (Community C). Although not all three actors were engaged directly in activities of wildfire resilience, they formed key roles within the context of rural community resilience to natural hazards (including wildfire) and had active roles working with formal and informal volunteers.

Across the three initiatives, 10 individual interviews, two document reviews ${ }^{[3]}$, two focus group/workshop discussions and five participant observations were conducted with 24 participants between June 2017 and December 2018 (Fig. 4, Table 1). Face-toface qualitative data collection methods exposed the first author to the experiences of formal and informal volunteers and volunteer leaders, adding to the second author's extensive knowledge of community response to rural fire in New Zealand and existing research relationships with the Rural Fire Authority (now FENZ). Building relationships through this research engagement was essential to support the development of a transformational research approach that was grounded in participants' experiences and perspectives. It was important to understand their personal ambitions and challenges for creating the level of community and organizational resilience they felt was needed at the time. Figure 4 shows how the four steps of our coinquiry corresponded with the time line of our data collection for developing systemic co-inquiry.

Table 1. Research activities documented as part of the co-inquiry across three scales.

\begin{tabular}{lccc}
\hline \hline Sites & $\begin{array}{c}\text { Participant } \\
\text { observations }\end{array}$ & Interviews & $\begin{array}{c}\text { Focus } \\
\text { groups }\end{array}$ \\
\hline Community: Community A & 3 & 2 & $1(\mathrm{n}=5)$ \\
Brigade: Community B & 1 & 2 & $1(\mathrm{n}=9)$ \\
Regional office: Community C & 1 & $6^{\ddagger}$ & nil \\
\hline
\end{tabular}

${ }^{\dagger}$ Two documents were also reviewed, one from Community A and one from Community B.

"Includes interviews with officers in other regions also, $\mathrm{n}=5$.

Following an initial introduction, we contacted the individuals and worked with them to document the methods they were developing to support their efforts of identifying and responding to vulnerability. For example, Actor-leader One was proposing a community resilience plan and set of engagement and research activities to support localized initiatives in disaster resilience building that could be potentially networked across remote areas of New Zealand. Actor-leader Two was developing a survey of members to support joint five-year (succession) planning and strategic development of the brigade relative to brigade member interests and priorities. Actor-leader Three shared a concern with their urban regional fire officer counterpart about remote communities being isolated during emergencies and potentially disengaged from formal emergency responders. As a co-inquiry researcher, the first author walked alongside these actors for a period to understand their world and appreciate their concerns and challenges. Data were analyzed in two ways: through dialogue with the key actor participants, ensuring an understanding of their drivers and motivations, and through reflective thematic analysis of our discussions and observations.

Our interactions with participants' contexts varied. For the spontaneous volunteer community, a series of emails, review of resilience plans, phone conversation, meetings, a workshop (focus group), and participant observations of a community event including incidental interviews, took place with Actor-leader One. For the brigade community a series of phone conversations, review of succession plans, two meetings, and participant observations with Actor-leader Two and attending a brigade training evening were held. During the brigade training evening a continuous interview was held (this was like a focus group discussion but with people entering and leaving) with three to six brigade members at a time (nine in total) as they took a break from rotating through a set of training activities. For the remote community engagement, a reflective interview was held with one of the response agency officials (Actor-leader Three) 
Fig. 3. Co-inquiry actors' boundaries overlaying a map showing the number and location of rural and urban fire brigades across New Zealand (source: FENZ 2019b). Inset study areas and resilience practice "community" sites in which actors were addressing vulnerabilities.

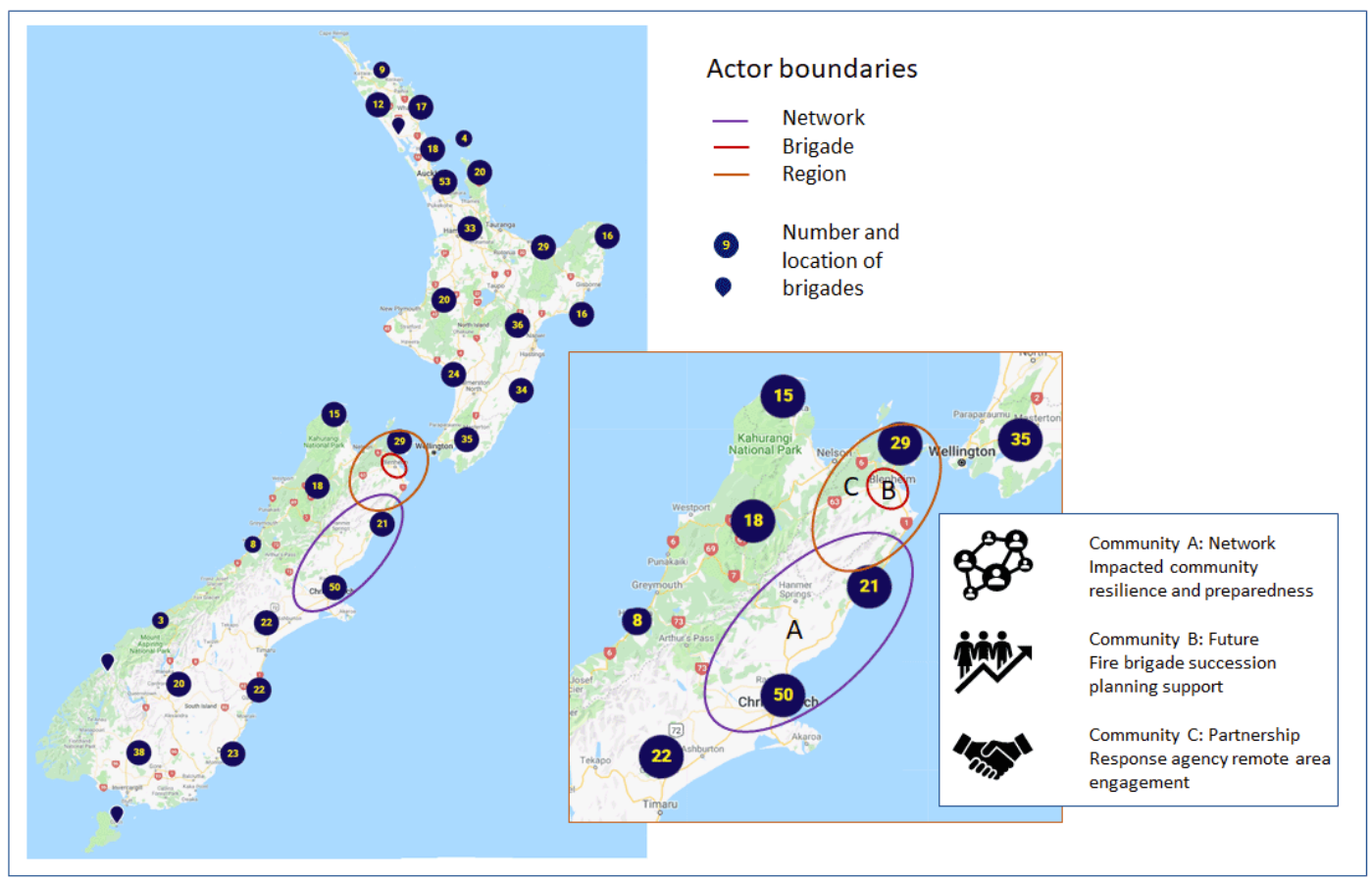

participating in joint response agency engagements of remote communities $^{[4]}$. From these interactions we learned about the circumstances that contributed to our actor-leaders' recognition of and response to vulnerability in the communities they worked with. Clearly there was more interaction than is captured by the focused data collection methods noted above.

\section{FINDINGS}

In developing a systemic co-inquiry we used an approach that could characterize and gain insight to our participants' worlds via their initiatives. This required iterative and judicial thinking between developing analytical themes and their interpretation with participants. It was important to be able to represent context together with the participants rather than extraction of research themes that could not demonstrate relationship to context. Four themes were chosen to illustrate: (i) the systems that participants were working with (based on participants' descriptions, documents, and participant observations), (ii) characteristics of leadership they demonstrated (based on participant observations and interviews), (iii) the vulnerabilities in their system that they had identified (based on participants' descriptions and participant observations), and (iv) some of the lessons and insights gained from research observations and reflections (based on participant observations, documents, workshop, and interviews). Following the first four steps of Box 1 and working iteratively between steps, our approach drew from systems techniques (Vickers 1965, Checkland and Casar 1986) used in organizational change to articulate the current situation from which change was sought. We did this based on the agency of our actor-leaders and the situations they described (or were dealing with) where volunteer and community interactions took place (to demonstrate the boundaries between existing formal/informal institutions). Additional insight was gained into their perceived limitations of the system (the boundaries of "normal" in institutionalized responses). Limitations experienced by our actor-leaders and possible means by which they might be overcome provide initial findings.

\section{Organization scale and description}

Participants operated within three levels of organization: disaster affected community, composite brigade, and regional FENZ. Two were formal (associated with FENZ) volunteer support roles, and one worked with volunteers in an informal capacity (as an emergent earthquake response volunteer leader). The disasteraffected community comprised those impacted by the 7.8 magnitude earthquake in Culverden near Kaikōura on 14 November 2016 including several inland and coastal townships and rural areas throughout North Canterbury and Marlborough regions. The brigade has a defined serviceable area and supports a population of 2418 people with associated industries (including forestry, air force, and wine growing) and provides back-up support across four other brigades and townships (StatsNZ 2018a, FENZ 2020a). Whereas, the region has a responsibility for 29 brigades and services a population of 47,340 people across a local government area with diverse terrain, land use, and industries including forestry and viticulture (StatsNZ 2018b, FENZ 2020b). Across the region the demographics vary from medium density urban center (120 per square $\mathrm{km}$ ) to rural and more remote areas with an overall population density of 4.5 people per square $\mathrm{km}$ (StatsNZ 2018c). 
Fig. 4. Time line of research engagements alongside co-inquiry steps for developing a systemic co-inquiry (Box 1).
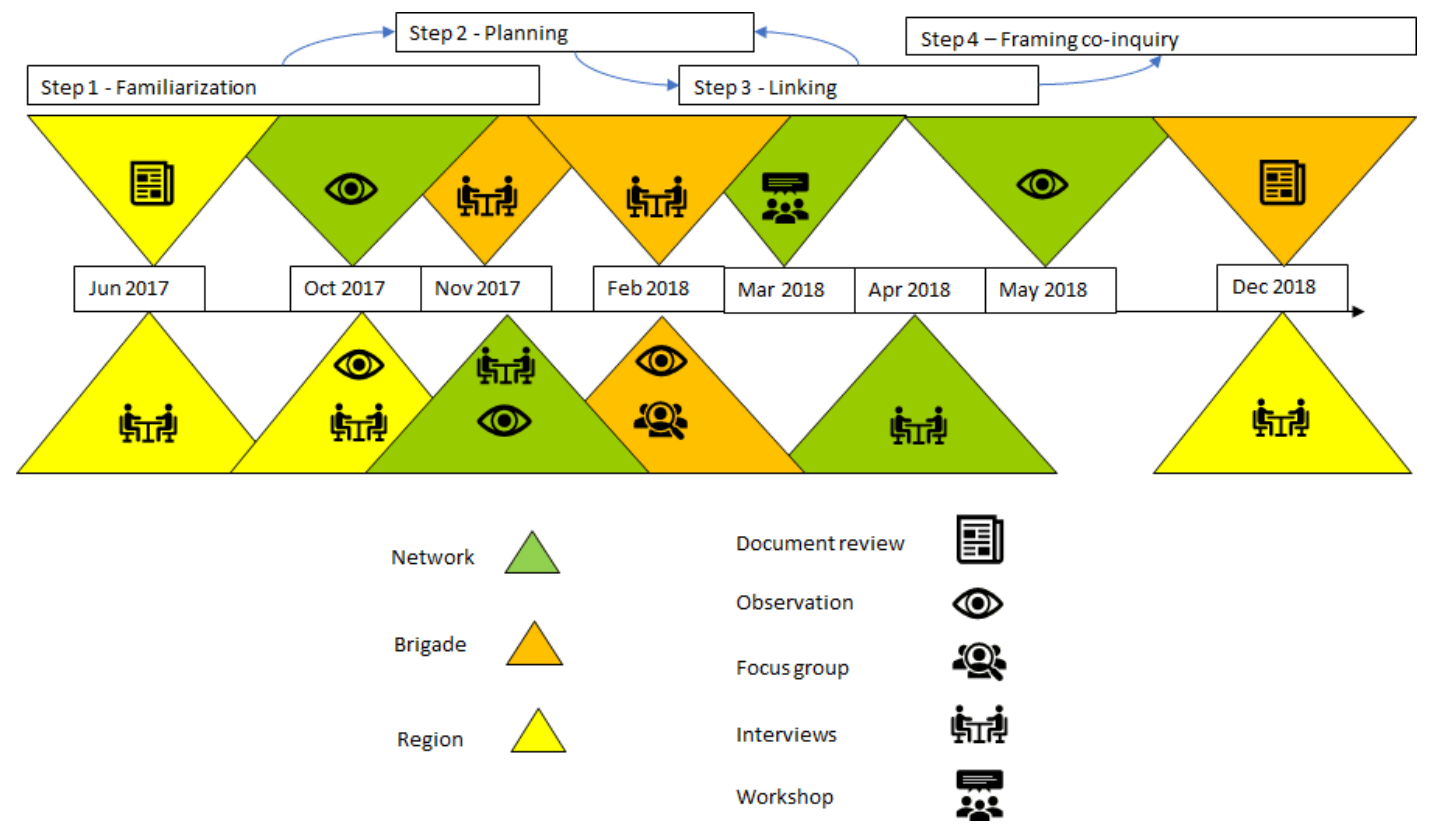

The community of more than 2000 people who informally responded to the 2016 Kaikōura earthquake became a spontaneously mobilized network of volunteers (Cradock-Henry et al. 2018). The informal community-based network was an emergent group of volunteers that self-organized around the catering business of a local entrepreneur and former trauma counsellor. The networks and organizational resources of key Actor-leader One became critical assets to supporting others in response to their isolation from the effects of the earthquake. The brigade organization was part of an existing institutional arrangement between FENZ (and formerly New Zealand [Urban] Fire Service [NZFS] and Rural Fire Authority [RFA]) and local communities that volunteer in brigades. The initiative of our key Actor-leader Two was part of a brigade that retained a stable number of volunteers, had good diversity (gender and age demographics but not necessarily ethnicity), was supportive of inclusive brigade leadership approaches, and had some limitations in availability of brigade members to respond to call outs. Actor-leader Three was a regional emergency response manager who had responsibility for supporting brigades, providing regional leadership and links to FENZ. As a sparsely populated region covering a large area experiencing a range of natural hazards, rescues, and road accidents, alignment with other response agencies was important.

Each actor-leader was nested within different scales and types of community and boundaries of organization (Table 2). Community A was connected through a network of retail businesses primarily aligned with food services, and a community of Facebook users that provided a link between people in need who had been cut off from communication lines following the earthquake and those wanting to support them. This could be best described as a digitally connected community hub, although it also involved in-person volunteering activities arising from a spontaneous community response. The types of community connected through Actor-leader One's network and outreach also included members of the emergency response effort including helicopter pilots, responses agencies, and links to local and national political leaders. The brigade was connected to community of families and businesses from which volunteers came as well as the wider community it served (Community B) and other local urban and rural brigades and their communities. Actor-leader Three provided a connection between emergency response agencies ("Urban" Fire Services and Police) as well as the wider organization of FENZ regions and central command. The community they served included the full set of brigades across the region and regional communities impacted by fires and other hazards and emergencies, including those in remote parts of the region (Community $\mathrm{C}$ ).

\section{Leadership characteristics}

We characterized these three leaders as part of an initiative to help others less able to help themselves through change or disruption. Actor-leader One self-organized and assembled spontaneous community volunteers to provide an informal volunteer response to community need by gathering and couriering food and other essential supplies into earthquake isolated communities and households. Actor-leader Two selforganized with other brigade volunteers and played a supportive role in leadership by helping the brigade to identify steps toward developing a five-year strategy and succession plan to support the development of the brigade. Actor-leader Three was a part of a collaborative agency effort to unite emergency services and reach out to geographically isolated communities within the region to increase awareness and encourage local self-reliance in response to multiple possible hazards. There were no institutional incentives for any of these leaders to perform these tasks; all were 
Table 2. Type of leadership, vulnerability characteristics and aspect, and extension beyond institutional boundaries.

\begin{tabular}{|c|c|c|c|}
\hline Type of leadership & Vulnerability characteristics & Vulnerability aspect & Extension beyond institutional boundaries \\
\hline Emergent leadership & $\begin{array}{l}\text { Essential needs: affection, hospitability, } \\
\text { food, water, connection }\end{array}$ & Disaster isolated communities & $\begin{array}{l}\text { Immediate response coordination, connection with } \\
\text { impacted individuals, harnessing and delegating } \\
\text { support, beyond helplessness (empowerment) }\end{array}$ \\
\hline Supportive leadership & $\begin{array}{l}\text { Brigade sustainability: inclusivity, } \\
\text { diversity, succession }\end{array}$ & Future brigade community & $\begin{array}{l}\text { Member expression of direction and desired future, } \\
\text { organizational development, coordination and } \\
\text { planning beyond brigade norms (inclusivity) }\end{array}$ \\
\hline Cooperative leadership & $\begin{array}{l}\text { Remote outreach: connection, } \\
\text { engagement, coordination }\end{array}$ & Isolated remote communities & $\begin{array}{l}\text { Coordination of resources to access remote areas and } \\
\text { encourage engagement through joint response agencies } \\
\text { information session, lifting motivational constraints } \\
\text { (awareness) }\end{array}$ \\
\hline
\end{tabular}

self-generated initiatives in response to their personal view of need.

Our emergent leader (Actor-leader One) noted how a formal emergency response organization (not FENZ) was ill-equipped to handle community willingness to act, and had not adequately conceptualized how it might work with communities.

\section{... I want to work with them but I don't believe they know what to do with us and they're in fear of us. I honestly believe that they don't know how, and that's exactly what he said, "Oh I don't know how you would. We haven't worked out what the place of community is."}

Several examples from past experiences where communities had self-mobilized were drawn upon to indicate there had been very little learning and institutional change with respect to supporting and working with informal emergency responses.

\begin{abstract}
We've had the Canterbury earthquake, we had the student army [Student Volunteer Army created as an emergent student emergency response body], the farmers come, you know like they've had all of those other groups from the Canterbury earthquake come, Rangiora express, everything and they've had all that learning but they've done nothing with that learning. Obviously now we've had Kaikōura earthquake, we've appeared. We're saying let's do something together, lets help. They're not willing to budge. So therefore, I think that, for me, it's like they need to understand that the community is their biggest power, biggest tribe, you know, the biggest man power that they have to work to their advantage and they're choosing not to use it.
\end{abstract}

Actor-leader Three, had more constructive interactions in remote areas where the local community were often the first responders; and, as part of a formal response organization, the rural brigades within his remit often worked closely with the non-aligned informal volunteers to respond to wildfires. He indicated some cultural constraints and opportunities that existed for giving this local formal institution (rural brigades) more capacity to mediate between rural and remote communities and formal response agencies.

Communities have capacity to and do respond immediately to emergencies, they have resources and abilities to help; response agencies (like the rural fire brigades) - when they arrive on the scene - work with this existing capacity. Sometimes the media works against the response effort broadcasting a picture of being ignored when people are actually working with agencies. Sometimes timing might be the issue, an earlier broadcast perhaps before the response agency has arrived, but they don't actually go back and pick up the story to say what has happened. (notes from unrecorded interview)

Actor-leader Three was a proactive voice in local media to indicate constructive interactions between formal and informal response organization. He also supported preparedness for wildfire risk through highlighting the vulnerabilities of places visited by taking and sharing local images of the wildfire dangers with residents; and worked with other agencies to gain stronger youth engagement in remote area emergency response.

A key focus for Actor-leader One was ensuring that community engagement led to actionable change in communities, so being present was not enough. Actor-leader One felt the need to leave a legacy of resilience with people through developing tools and plans to help them help themselves in future. Actor-leaders Two and Three showed similar intent.

\section{Identified vulnerabilities}

Our participants saw the vulnerabilities of others, which we identified as a motivating influence on their initiative, and type of leadership (Table 2). Each had distinct views of vulnerability: (i) on rural communities isolated from each other by natural hazard events, (ii) on maintenance of the brigade and its future leadership, and (iii) on remote communities disconnected by distance from formalized emergency response organizations. Actor-leader Two's draft five year plan development included attention to succession planning as an important instrument to retain interest of junior members in brigade activities, and potentially rollover more experienced brigade members into brigade support roles.

There should also be room for members to stand down a level after time if they feel the need and still contribute to the brigade as a valued member all be it at a reduced level. There is a possibility to create a position most suitably attached to the training officer of succession planning both for the individuals and the brigade. This would mean a more formal discussion with members about their aspirations regarding advancement and other assessments. These meeting discussions would need to be held at regular intervals possibly annually to ensure 
relevance to individual needs. (Brigade draft five year strategy, "Volunteer advancement training and succession planning")

Vulnerabilities for Actor-leader Two were around the future brigade and how current social investments in planning that were inclusive of brigade members could support what that looked like. A survey was conducted by Actor-leader Two to garner this knowledge. Types of training needs and services brigade members would like to support including motor vehicle accidents and vegetation fires were part of their considerations.

Actor-leader One used the extensive network of connections rallied during the initial earthquake response to promote awareness of the community effort and resilience characteristics. This network was utilized and extended to champion and seek resources from the public and private sector for the development of bottom-up community resilience plans. The objectives of that plan included eight areas of desired outcome recognized as lacking by Actor-leader One, to support community resilience.

Objectives of the community resilience plan:

- To strengthen community and individual resilience.

- To foster a sense of security and safety within communities and rural villages.

- To ensure all sectors of our communities are sustainable prior to and post-disaster.

- To empower individual communities and villages to form adaptive response strategies.

- To form community coalitions and coordinated regional response strategies.

- To coordinate timely response, lines of communication, basic life essentials to disaster-hit communities.

- To minimize immediate and on-going trauma and distress in disaster affected communities.

- To collaborate with institutions to serve a gap in the existing emergency response system. (Community Resilience Draft Plan, "ThriveMe Resilient Communities Plan")

The planning initiative aimed to look beyond immediate local needs into future responses and toward other potentially isolated rural and remote communities to proactively prepare for future earthquake and other hazard events. The initiative of Actorleader One struggled to get investment from formal emergency organizations and community funds provided by central government to realize this plan despite local community and business support for the initiative.

\section{Lessons and insights: listening and reflecting on experience}

As a result of our engagements, through listening to our participants and reflecting on their experience we learned more about their circumstances. Although our focus was primarily with FENZ, we used the experience of our informal volunteer leader as an external view of working with response agencies and possibility for further learning. Each of our actor-leaders were seeking to facilitate change to build resilience of disaster affected communities, future brigades, and remote communities. We saw opportunities to work collaboratively with our participants to support community resilience to wildfires. Initially, we note three areas in which the initiatives could be supported through applications of systems thinking tools such as developing a boundary critique or designing systemic interventions (Midgley and Rajagopalan 2020), e.g., by piloting community resilience plans, designing reciprocal activities that support brigade and community resilience, and evaluating outcomes of outreach initiatives. The following experiences presented opportunities to learn both as independent systems and from each other.

1. Emergent emergency volunteers were highly effective in spontaneous community organization. They gathered and distributed resources, vetting high numbers of casual volunteers into their response operations, and coordinating the response effort through pulling in resources to enable food and other essentials delivery into isolated areas. However, they experienced a clash in operational logic with the formal response agencies: they held different priorities in managing risk, leading to a conflict in operations. An authoritarian attitude and perceived lack of humanity decreased confidence in the agency services and how they were valued by affected individuals, as it limited the autonomy of individuals and downplayed the relevance of local knowledge. Essential human needs were not met by official responses but unofficial ones that provided more open lines of communication with isolated families and individuals. An emergent need is to improve relations between community and central agency, perhaps through co-developing resilience plans or resourcing communities to develop these as a pilot project.

2. The number of brigade callouts was a potential measure of sustainability on brigade membership relative to the ability to attend. The opportunity to have a more proactive presence in the community by raising awareness and preparedness for wildfire, and to allow less experienced firefighters to come on board, as well as retaining more experienced volunteers through non-firefighting roles could support the relative resilience of brigades and the communities they served. Individuals within the brigades felt the support of other brigade members; and families and businesses provided informal brigade support networks, e.g., by looking after children or businesses while members attended callouts or training. However, brigades were not typically trained in trauma mental preparedness. A focus on resourcing through equipment and training in its use downplayed the social and human side of skills and capabilities. There is a need to value other roles within the brigade outside of firefighting, as potential means for reducing callouts and sustaining brigades through building more resilient communities.

3. Response agencies were unable to attract significant interest when they visited remote areas as single agencies, leaving them with limited means for raising awareness in these areas. Joining forces with other agencies to visit remote areas of the region worked more effectively, as more community members were interested in attending information evenings with more than one topic being discussed. Information reached its intended audience and opportunities to influence higher levels of self-reliance in these communities were taken. Although the effectiveness of the initiative has not 
been examined, the willingness of participants to stay on after meetings and keep the conversation going was an indication of valued time spent. There may be a need to demonstrate the value of this type of engagement and outreach initiative to the centralized agency, if it does make a difference to community resilience and therefore contribute better outcomes for wildfire management.

The value of bringing these independent resilience building activities of volunteer leaders into focus for applying a systemic co-inquiry opens potential areas of alignment in these initiatives to generate coordinated resilience outcomes at different scales. Facilitating joint inquiry processes to support critical engagement with institutional constraints and opportunities to complement and sustain efforts in generating rural community resilience to the changing risk of wildfires is warranted.

\section{DISCUSSION}

Our key actor-leaders witnessed and responded to perceived vulnerabilities, providing a context to discuss how resilience is generated (Larsen et al. 2011, Manyena et al. 2013) and to strengthen alignments between formal and informal volunteering activities at different scales and sites. Generating solutions to the problems encountered was a factor underlying the agency of our three actor-leaders, i.e., community resilience planning, brigade succession planning, and remote community outreach activities. Three areas of vulnerability noted were in (i) disaster impacted communities, (ii) a future fire brigade, and (iii) remotely located communities within a region. These three initiatives demonstrate how responses to vulnerabilities can support resilience as a process. As noted by Aldunce et al. (2016), there are few empirical studies that have informed how disaster resilience is practiced. Our actor-leaders initiated an effort to empower, include, and increase awareness of those vulnerable through what we observed as emergent, supportive, and collaborative leadership. All initiatives were self-generated in response to observed vulnerabilities, and none were formally derived or incentivized. Findings suggest generating community resilience may depend less on specific functions as traditionally institutionalized (e.g., by firefighting roles of rural fire brigades), or existing institutional dependencies (e.g., emergency responses agencies coming to the rescue of communities) and more on situated agency alignment across different problem-solving initiatives. Thinking about collective or team resilience as an emergent property will require different types of theorization on resilience as both process and outcome (e.g., Bowers et al. 2017).

This research agrees with other findings that show that progress is being made toward shifting the focus of resilience from responding to hazard events (Manyena et al. 2013, Jacobs and Cramer 2017) toward an emergent property of interactions between people and perceived vulnerabilities. Having local knowledge and an ability to build capacity where there were limitations were two key underlying aspects of our actor-leaders. Furthermore, they shared key underpinning drives associated with community resilience that valued self-reliance and collaborative responses operating at different scales and with different communities. Larsen et al. (2011) argue that we need to develop a "system-actor" relational concept of stakeholder agency in which an emerging storyline (as a negotiated normative process) generates a legitimate vision of resilience. Similarly to
Larsen et al. (2011), offering opportunities to learn from each other could generate better alignment between actor-leaders' initiatives and lead to a stronger intermeshing of activities (Aldunce et al. 2016).

At the same time, some actions undertaken could be supported by independent research and evaluation to reflect on and better understand the efficacy of actor-leader initiatives in achieving desired outcomes. This is important, not just for the reflection and improvement of actor-leaders but for gaining the support from centralized authorities to continue with initiatives that both generate (process) and demonstrate (outcomes) community resilience. There are limitations with a lack of central appreciation or support of these locally generated initiatives, as shown: (i) because of a lack of know-how on working with communities; (ii) a current focus on physical training needs and brigade capacities, rather than social and psychological needs; and (iii) possible coordination of inter-agency response centrally rather than locally, with a lack of understanding of how outreach efforts are performing. As researchers, we may not be able to directly reverse the power differentials of the past (Vallance 2012, Mamula-Seadon and McLean 2015), be they top-down approaches or locally exclusive cultures. However we can start more critically engaged conversations and collaborative inquiry into building institutional reflexivity around volunteering and community resilience to wildfire challenges. As noted by Boström et al. (2017), we do need to create more self-confronting institutions, prepared to examine the unintended consequences, e.g., that disempower, exclude, or marginalize vulnerable communities.

Second, developing the novel method of systemic co-inquiry provides a wider perspective on how resilience and connections across different scales and intents of local resilience building can be realized. For example, accommodating difference in interpretative dimensions, we need to reflect on contrasts between advantages of formal response organizations supporting communities and working with them expressed by Actor-leader Three compared with inimicality and lack of knowhow experienced by Actor-leader One. Better realizing the strengths of working together to avoid the power struggles of inconsistent operational logics can be helped by valuing people doing different things to support community resilience and to build trust and coordination. As noted by Colvin et al. (2014), relational capital plays an important but understudied role in transformational change; social learning and adaptation can become part of systemic innovations if learning opportunities, like those initiated by our participants, can be developed. Alignments between scales and sites of initiatives, where actors can collectively examine the limits of existing formal and informal institutions, can help understand environmental changes impacting on volunteer organization (whether they are changing demographics, more casual or spontaneous volunteering styles, or increased wildfire risk due to climate change) and make appropriate adaptations to new experiences.

Initiating systemic co-inquiry (Ison 2010) and analysis of issues discussed within the literature, our examination of wildfire volunteering in a changing social and ecological environment has contributed to understanding community resilience in New Zealand from the perspective of volunteer leaders. Resilience 
requires the agency of local actors, to help locate and work with those in areas of vulnerability, underlined by an ethic of concern for the other. However, our research shows the self-initiated agency of our key actor-leaders that identifies weakness in existing formal institutions and norms of volunteer practice, to also require top down support. Creating linkages between different sites and scales of organization requires a social awareness that cannot be assumed to exist. These findings have developed through collaboration with practitioners, to ground systemic coinquiry into community resilience as an ongoing relationship between research and practice. Our aims have been to support actor-leaders who reach the limits of and extend beyond established institutional boundaries to help create reflexive awareness, e.g., acknowledgment and support for non-firefighting roles of volunteers. Practices of institutional reflexivity identified in this setting demonstrates purposeful capacities for transformation, of our key actor-leaders, in response to vulnerabilities of others, i.e., through disruption, lack of succession, or isolation. Institutional reflexivity is a relational dimension of responding to risk and vulnerability that needs further exploring and expanding, if it is to serve transformational resilience within changing social and ecological environments.

\section{Volunteer capacities for building rural community resilience}

As has been acknowledged by Whittaker et al. (2015) the definition and reach of volunteering for emergencies has failed to consider the many informal ways people are connecting to help those in need during disasters. Although acknowledging the importance of informal volunteers and appreciating the demand for more flexible and inclusive approaches to volunteering, we found the activities of formal and informal volunteers overlapping in New Zealand's rural setting. Although there is a need to better understand how these two groups can work together, acknowledging the different operational logics of formal and informal rural institutions in emergency response (McLennan et al. 2020), our research with actor-leaders provides a basis for examining how coordination and cooperation can be achieved between local sites of resilience building at different scales. These findings offer further insight on the importance of local deliberation and agency in identifying and addressing vulnerabilities in hazard assessments (Barnett et al. 2008, HenlyShepard et al. 2015). Our findings move beyond indication of resilience as something that can be known independently of local awareness. Specifically, we have focused on the interpretative dimensions of resilience, experienced at the frontline of volunteer activities, identified different kinds of leadership in operation, and initiated a path for social learning (Ison et al. 2015, Aldunce et al. 2016) with our participants.

Even though our key actor-leaders value both informal and formal disaster response capabilities, findings show the potential to realize these more fully. Diversity in volunteer roles beyond firefighting is not yet fully developed in FENZ volunteer recruitment practice. This area warrants attention through further co-inquiry including understanding what constitutes an appropriate diversity of volunteer brigade roles, and how formal and informal institutions complement and support community wildfire resilience. The findings from this research indicate how social and institutional dimensions of wildfire risk management can become more adaptive and inclusive, addressing formal volunteering culture and legal liability (Whittaker et al. 2015,
McLennan et al. 2020) as legacies that may constrain rather than enable the building of resilience. The challenge presented is that traditional or existing institutions or norms do not align in the spaces that our participants are active, as shown by their initiatives: empowering community-initiated resilience planning, inclusive brigade succession planning, and raising remote community awareness for wildfire preparation. Therefore, better understanding developed around institutional reflexivity (realizing the limits of existing institutions for responding to changing social-ecological conditions), as a practice to be valued and aligned across different scales and centers of volunteer action may be required.

The findings from this research are limited by the place and context-based direction through which it was developed. Its findings need to be tested through other settings and considered against the dynamics of working with different types of leadership and communities in building community wildfire resilience. Furthermore, the application of systemic co-inquiry as researcher-practitioner collaborative research methodological framework aimed at social learning needs to be further explored for transformational change initiatives.

\section{CONCLUSION}

A changing social landscape with fewer people on farms, aging demographics and hotter, drier conditions are increasing wildfire risk in New Zealand's rural areas, placing pressure on volunteer rural fire brigades. These pressures are expected to grow in coming decades, providing a test case to inform policy and practice elsewhere. Looking beyond firefighting roles of volunteers, we have argued that systemic approaches are needed to understand and motivate resilience transformations across scales of organization, to support community self-reliance, increase reflection and self-awareness, and coordinate effort. Drawing on participants' experiences in multi-hazard rural settings, findings show the importance of institutional reflexivity as a vehicle for change. Here historic norms have reached their limits and new social initiatives have emerged, motivating action aimed at helping others based on empowerment, inclusion, and awareness. These voluntary activities in both formal and informal volunteering organizations are indicative of generative resilience and the potential for learning that, if properly acknowledged, can enable constructive transformation from emergency service provision to an enabled partnership between communities and response agencies.

Findings support those of McLennan et al. (2020) that look to legitimate and authorize the support of unaffiliated volunteering in building community resilience through the co-production of emergency management services. We add systemic co-inquiry as a methodological approach that can support researcherpractitioner collaboration in building community resilience to wildfires. By connecting with the initiatives of our three actorleaders, we have established a baseline for inquiry that links across different communities (networked, brigade, and remote), sites (disaster impacted, urban-rural fringe, and geographically isolated), and scales (inter-regional, township, and regional). As FENZ consolidates its mandate and centralizes its resources, we suggest maintaining an awareness of local initiatives (at different scales) that can support practical resilience building measures and volunteering systems that generate higher levels of community 
self-reliance. Further development of our systemic co-inquiry could examine the effectiveness of initiatives, their alignment in achieving resilience outcomes, and where support for addressing vulnerabilities is hampered by traditional community ties and institutions (Skutsch and Turnhout 2018). Building on these insights suggests an opportunity for further developing institutional reflexivity, e.g., through feedback between formal volunteering and informal community actions as a vehicle for change for more resilient wildfire futures in New Zealand and elsewhere.

${ }^{[1]}$ In this paper we refer to institutions as norms and reflexivity as a challenge or questioning of assumptions. We define institutional reflexivity as reflecting on how we (our activities and organization) are shaped by norms and rules, that are based on past states of knowledge and experience (judgement of facts and values) that may no longer be relevant but are open to revision (see Fig. 1).

${ }^{[2]}$ We note that a framework provides guidance on process and how but is not prescriptive because actual methods need to emerge from the context and be relevant to the setting and specific problem focus that cannot be known in advance of the research being conducted.

${ }^{[3]}$ Community resilience plan and brigade succession plan, both in draft, were also reviewed

${ }^{[4]}$ Further interviews conducted with other FENZ regional fire officers were not included in this analysis, to ensure that all participants were nested within the same broad geographic region.

Responses to this article can be read online at: https://www.ecologyandsociety.org/issues/responses. $\mathrm{php} / 12474$

\section{Acknowledgments:}

This research was funded by the Resilience to Nature's Challenges National Science Challenge through the New Zealand Ministry of Business Innovation and Employment, supplemented by Scion to enable the writing of this paper, and supported by agencies represented on the Scion Rural Fire Research Advisory Committee. The authors thank the disaster impacted communities, brigade, principal rural fire officers, and volunteer managers for their willingness to participate and Simon Wegner and Tara Strand (Scion), Nick Cradock-Henry (Manaaki Whenua Landcare), Sally Chesterfield and Jim Herdman (Fire and Emergency New Zealand), Larina Kay Tiffen (Miss Lilly's Angle Trust), and Ray Ison and Natalie Foster (Open University, UK) for reviews of earlier drafts. Ray Ison also reviewed to the appendix. Further thanks for the helpful comments from Ecology and Society anonymous reviewers.

\section{Data Availability:}

Institutional process for ethics approval was followed and the project approval number was J60044-04 with a project start date of 30
November 2016. The data that support the findings of this study are available on request from the corresponding author $[A G]$.

\section{LITERATURE CITED}

Adger, W. N. 2006. Vulnerability. Global Environmental Change 16:268-281. https://doi.org/10.1016/j.gloenvcha.2006.02.006

Aldunce, P., R. Beilin, J. Handmer, and M. Howden. 2016. Stakeholder participation in building resilience to disasters in a changing climate. Environmental Hazards 15:58-73. https://doi. org/10.1080/17477891.2015.1134427

Alkema, A., N. Murray, and H. McDonald. 2013. "You can’t be selfish in the country": motivating, recruiting and retaining volunteer fire fighters in rural communities in New Zealand. New Zealand Fire Service Commission, Wellington, New Zealand.

Allan, C., R. L. Ison, R. Colliver, L. Mumaw, M. Mackay, L. Perez-Mujica, and P. Wallis. 2020. Jumping off the treadmill: transforming NRM to systemic governing with systemic coinquiry. Policy Studies 41:350-371. https://doi.org/10.1080/0144$\underline{2872.2020 .1726312}$

Allen, J., K. Hopper, L. Wexler, M. Kral, S. Rasmus, and K. Nystad. 2014. Mapping resilience pathways of Indigenous youth in five circumpolar communities. Transcultural Psychiatry 51:601-631. https://doi.org/10.1177/1363461513497232

Baillie, B. R., and K. M. Bayne. 2019. The historical use of fire as a land management tool in New Zealand and the challenges for its continued use. Landscape Ecology 34:2229-2244. https:// doi.org/10.1007/s10980-019-00906-8

Barnett, J., S. Lambert, and I. Fry. 2008. The hazards of indicators: insights from the Environmental Vulnerability Index. Annals of the Association of American Geographers 98:102-119. https://doi.org/10.1080/00045600701734315

Berkes, F., and H. Ross. 2013. Community resilience: toward an integrated approach. Society \& Natural Resources 26:5-20. https://doi.org/10.1080/08941920.2012.736605

Blackman, D., H. Nakanishi, and A. M. Benson. 2017. Disaster resilience as a complex problem: why linearity is not applicable for long-term recovery. Technological Forecasting and Social Change 121:89-98. https://doi.org/10.1016/j.techfore.2016.09.018

Boström, M., R. Lidskog, and Y. Uggla. 2017. A reflexive look at reflexivity in environmental sociology. Environmental Sociology 3:6-16. https://doi.org/10.1080/23251042.2016.1237336

Bowers, C., C. Kreutzer, J. Cannon-Bowers, and J. Lamb. 2017. Team resilience as a second-order emergent state: a theoretical model and research directions. Frontiers in Psychology 8:1360. https://doi.org/10.3389/fpsyg.2017.01360

Brenkert-Smith, H., P. A. Champ, and N. Flores. 2012. Trying not to get burned: understanding homeowners' wildfire riskmitigation behaviors. Environmental Management 50:1139-1151 https://doi.org/10.1007/s00267-012-9949-8

Brown, V., J. Harris, and J. Russell, editors. 2010. Tackling wicked problems: through the transdisciplinary imagination. Earthscan, London, UK. 
Chaffin, B. C., and L. H. Gunderson. 2016. Emergence, institutionalization and renewal: rhythms of adaptive governance in complex social-ecological systems. Journal of Environmental Management 165:81-87. https://doi.org/10.1016/j.jenvman.2015.09.003

Checkland, P. B., and A. Casar. 1986. Vickers' concept of an appreciative system: a systemic account. Journal of Applied Systems Analysis 13:3-17.

Cochrane, W., and D. Maré. 2017. Urban influence and population change in New Zealand. Policy Quarterly 13:61-71. https://doi.org/10.26686/pq.v13i0.4556

Collins, K., and R. Ison. 2009. Jumping off Arnstein's ladder: social learning as a new policy paradigm for climate change adaptation. Environmental Policy and Governance 19:358-373. https://doi.org/10.1002/eet.523

Colvin, J., C. Blackmore, S. Chimbuya, K. Collins, M. Dent, J. Goss, R. Ison, P. P. Roggero, and G. Seddaiu. 2014. In search of systemic innovation for sustainable development: a design praxis emerging from a decade of social learning inquiry. Research Policy 43:760-771. https://doi.org/10.1016/i.respol.2013.12.010

Coulthard, S. 2012. Can we be both resilient and well, and what choices do people have? Incorporating agency into the resilience debate from a fisheries perspective. Ecology and Society 17(1):4. https://doi.org/10.5751/ES-04483-170104

Cowlishaw, S., L. Evans, and J. McLennan. 2008. Families of rural volunteer firefighters. Rural Society 18:17-25. https://doi. org/10.5172/rsj.351.18.1.17

Cradock-Henry, N. A., J. Fountain, and F. Buelow. 2018. Transformations for resilient rural futures: the case of Kaikoura, Aotearoa-New Zealand. Sustainability 10:1952. https://doi. org/10.3390/su10061952

Cumming, G. S. 2013. Scale mismatches and reflexive law. Ecology and Society 18(1):15. https://doi.org/10.5751/ES-05407-180115

Cumming, G. S., D. H. M. Cumming, and C. L. Redman. 2006. Scale mismatches in social-ecological systems: causes, consequences, and solutions. Ecology and Society 11(1):14. https://doi.org/10.5751/ES-01569-110114

Curtin, C. G., and J. P. Parker. 2014. Foundations of resilience thinking. Conservation Biology 28:912-923. https://doi. org/10.1111/cobi.12321

De Groot, W. J., and M. D. Flannigan. 2014. Climate change and early warning systems for wildland fire. Pages 127-151 in Z. Zommers and A. Singhm editors. Reducing disaster: early warning systems for climate change. Springer, Dordrecht, The Netherlands. https://doi.org/10.1007/978-94-017-8598-3 7

Department of Foreign Affairs and Trade (DFAT). 2017. Te Ohanga Maori - The Maori Economy. DFAT, Wellington, New Zealand.

Ethos Consulting. 2017. Differentiating Strong and Struggling Volunteer Brigades. Fire and Emergency New Zealand, Wellington.

Fire and Emergency New Zealand (FENZ). 2017. 2017-2021 Statement of intent. FENZ, Wellington, New Zealand.
Fire and Emergency New Zealand (FENZ). 2018. Annual report. FENZ, Wellington, New Zealand.

Fire and Emergency New Zealand (FENZ). 2019a. Annual report - Pūrongo ā-Tau. FENZ, Wellington, New Zealand.

Fire and Emergency New Zealand (FENZ). 2019b. Find a Station. FENZ, Wellington, New Zealand. [online] URL: $\underline{\text { htps:// }}$ www.fireandemergency.nz/find-a-station/

Fire and Emergency New Zealand (FENZ). 2020a. Renwick Volunteer Fire Brigade. FENZ, Wellington, New Zealand

Fire and Emergency New Zealand (FENZ). 2020b. Marlborough Local Advisory Committee, Local area boundary. FENZ, Wellington, New Zealand.

Folke, C. 2006. Resilience: the emergence of a perspective for social-ecological systems analyses. Global Environmental Change 16:253-267. https://doi.org/10.1016/j.gloenvcha.2006.04.002

Foster, N., K. Collins, R. Ison, and C. Blackmore. 2016. Water governance in England: improving understandings and practices through systemic co-inquiry. Water 8(11):540. https://doi. org/10.3390/w8110540

Foster, N., R. Ison, C. Blackmore, and K. Collins. 2019. Revisiting deliberative policy analysis through systemic co-inquiry: some experiences from the implementation of the Water Framework Directive in England. Policy Studies 40:510-533. https://doi. org/10.1080/01442872.2019.1618816

Garmestani, A. S., and M. H. Benson. 2013. A framework for resilience-based governance of social-ecological systems. Ecology and Society 18(1):9. https://doi.org/10.5751/ES-05180-180109

Gidley, J. M., J. Fien, J.-A. Smith, D. C. Thomsen, and T. F. Smith. 2009. Participatory futures methods: towards adaptability and resilience in climate-vulnerable communities. Environmental Policy and Governance 19:427-440. https://doi.org/10.1002/ eet. 524

Glasswell, K., P. A. Singh, and S. McNaughton. 2016. Partners in design: co-inquiry for quality teaching in disadvantaged schools. Australian Journal of Language and Literacy 39:20-29.

Graham, L., W. Debucquoy, and I. Anguelovski. 2016. The influence of urban development dynamics on community resilience practice in New York City after Superstorm Sandy: experiences from the Lower East Side and the Rockaways. Global Environmental Change 40:112-124. https://doi.org/10.1016/j. gloenvcha.2016.07.001

Grant, A., and E. R. L. Langer. 2019. Integrating volunteering cultures in New Zealand's multi-hazard environment. Australian Journal of Emergency Management.

Halliday, J., S. Asthana, P. Hewson, and A. Gibson. 2013. Playing with fire: limitations of the big society for an emergency service. Public Policy and Administration 28:290-305. https://doi. org/10.1177/0952076712456232

Harris, M., D. Shaw, J. Scully, C. M. Smith, and G. Hieke. 2016. The involvement/exclusion paradox of spontaneous volunteering: new lessons and theory from winter flood episodes in England. Nonprofit and Voluntary Sector Quarterly 46:352-371. https:// doi.org/10.1177/0899764016654222 
Haski-Leventhal, D., and R. A. Cnaan. 2009. Group processes and volunteering: using groups to enhance volunteerism. Administration in Social Work 33:61-80. https://doi. org/10.1080/03643100802508635

Haski-Leventhal, D., and J. D. McLeigh. 2009. Firefighters volunteering beyond their duty: an essential asset in rural communities. Journal of Rural and Community Development 4:80-92.

Hayward, B. M. 2013. Rethinking resilience: reflections on the earthquakes in Christchurch, New Zealand, 2010 and 2011. Ecology and Society 18(4):37. https://doi.org/10.5751/es-05947-180437

Henly-Shepard, S., C. Anderson, K. Burnett, L. J. Cox, J. N. Kittinger, and M. A. Ka'aumoana. 2015. Quantifying household social resilience: a place-based approach in a rapidly transforming community. Natural Hazards 75:343-363. https://doi.org/10.1007/ \$11069-014-1328-8

Heron, J. 1996. Cooperative inquiry: research into the human condition. SAGE, London, UK.

Heron, J., and P. Reason. 1997. A participatory inquiry paradigm. Qualitative Inquiry 3:274-294. https://doi.org/10.1177/10778004$\underline{9700300302}$

Hong, S.-I., N. Morrow-Howell, F. Tang, and J. Hinterlong. 2009. Engaging older adults in volunteering: conceptualizing and measuring institutional capacity. Nonprofit and Voluntary Sector Quarterly 38:200-219. https://doi.org/10.1177/0899764008317207

Hustinx, L., F. Handy, R. A. Cnaan, J. L. Brudney, A. B. Pessi, and N. Yamauchi. 2010. Social and cultural origins of motivations to volunteer: a comparison of university students in six countries. International Sociology 25:349-382. https://doi.org/10.1177/026$\underline{8580909360297}$

Ison, R. 2010. Systemic inquiry. Pages 243-265 in Systems practice: how to act in a climate-change world. Springer London, London, UK. https://doi.org/10.1007/978-1-84996-125-7_10

Ison, R. 2016a. Transforming nature-society relations through innovations in research praxis: a coevolutionary systems approach. Pages 47-70 in B. Hubert and N. Mathieu, editors. Interdisciplinarités entre Natures et Sociétés: Colloque de Cerisy. Peter Lang, EcoPolis, Bruxelles, Belgium.

Ison, R. 2016b. Transdisciplinarity as transformation: a cybersystemic thinking in practice perspective. Pages 55-74 in D. Fam, J. Palmer, C. Riedy, and C. Mitchell, editors. Transdisciplinary research and practice for sustainability outcomes. Routledge, London, UK. https://doi.org/10.4324/9781315652184

Ison, R. 2017. Systems practice: how to act - in situations of uncertainty and complexity in a climate-change world. Second edition. Springer, Milton Keyes, UK.

Ison, R. 2019. Toward cyber-systemic thinking in practice. World Futures 75:5-16. https://doi.org/10.1080/02604027.2019.1568797

Ison, R., and C. Blackmore. 2014. Designing and developing a reflexive learning system for managing systemic change. Systems 2:119-136. https://doi.org/10.3390/systems2020119
Ison, R. L., K. B. Collins, and P. J. Wallis. 2015. Institutionalising social learning: towards systemic and adaptive governance. Environmental Science \& Policy 53:105-117. https://doi. org/10.1016/j.envsci.2014.11.002

Jacobs, D. B., and L. A. Cramer. 2017. Applying information network analysis to fire-prone landscapes: implications for community resilience. Ecology and Society 22(1):52. https://doi. org/10.5751/ES-09119-220152

Jakes, P. J., L. Kelly, and L. E. Langer. 2010. An exploration of a fire-affected community undergoing change in New Zealand. Australian Journal of Emergency Management 25:48-53.

Janssen, M. A., and E. Ostrom. 2006. Resilience, vulnerability, and adaptation: a cross-cutting theme of the International Human Dimensions Programme on Global Environmental Change. Global Environmental Change 16:237-239. https://doi. org/10.1016/j.gloenvcha.2006.04.003

Jenkins, E. 2007. Using cooperative inquiry and clinical supervision to improve practice. British Journal of Community Nursing 12:63-69. https://doi.org/10.12968/bjen.2007.12.2.22815

Kasl, E., and L. Yorks. 2002. Collaborative inquiry for adult learning. New Directions for Adult and Continuing Education 94:3-12. https://doi.org/10.1002/ace.54

Klinge, T. J. 2021. Foreign investments in New Zealand's agricultural sector and their regulation, 2001-2017. Globalizations 18(4):533-550. https://doi.org/10.1080/14747731.2020.1795427

KPMG. 2018. Agribusiness Agenda 2018. KPMG New Zealand, Wellington.

Langer, E. R. L., and S. Wegner. 2018. Wildfire risk awareness, perception and preparedness in the urban fringe in Aotearoa/New Zealand: public responses to the 2017 Port Hills wildfire. Australasian Journal of Disaster and Trauma Studies 22:75-84.

Larsen, R. K., E. Calgaro, and F. Thomalla. 2011. Governing resilience building in Thailand's tourism-dependent coastal communities: conceptualising stakeholder agency in socialecological systems. Global Environmental Change 21:481-491. https://doi.org/10.1016/j.gloenvcha.2010.12.009

Lavell, A., M. Oppenheimer, C. Diop, J. Hess, R. Lempert, J. Li, R. Muir-Wood, and S. Myeong, S. Moser, K. Takeuchi, et al. 2012. Climate change: new dimensions in disaster risk, exposure, vulnerability, and resilience. Pages 25-64 in C. B. Field, V. Barros, T. F. Stocker, D. Qin, D. J. Dokken, K. L. Ebi, M. D. Mastrandrea, K. J. Mach, G.-K. Plattner, S. K. Allen, M. Tignor, and P. M. Midgley, editors. Managing the risks of extreme events and disasters to advance climate change adaptation. A Special Report of Working Groups I and II of the Intergovernmental Panel on Climate Change. Cambridge University Press, Cambridge, UK. https://doi.org/10.1017/cbo9781139177245.004

Lawrence, J., F. Sullivan, A. Lash, G. Ide, C. Cameron, and L. McGlinchey. 2015. Adapting to changing climate risk by local government in New Zealand: institutional practice barriers and enablers. Local Environment 20:298-320. https://doi. org/10.1080/13549839.2013.839643

Le Heron, R. 1991. New Zealand agriculture and changes in the agriculture - finance relation during the 1980s. Environment and 
Planning A: Economy and Space 23:1653-1670. https://doi. org/10.1068/a231653

Livi, S., V. De Cristofaro, A. Theodorou, M. Rullo, V. Piccioli, and M. Pozzi. 2020. When motivation is not enough: effects of prosociality and organizational socialization in volunteers' intention to continue volunteering. Journal of Community \& Applied Social Psychology 30:249-261. https://doi.org/10.1002/ casp. 2446

Lough, B. 2018. Literature review for the state of the world's volunteerism report 2018: building resilient communities in a turbulent world. UN Volunteers, Bonn, Germany.

Mamula-Seadon, L., and I. McLean. 2015. Response and early recovery following 4 September 2010 and 22 February 2011 Canterbury earthquakes: societal resilience and the role of governance. International Journal of Disaster Risk Reduction 14:82-95. https://doi.org/10.1016/j.ijdrr.2015.01.005

Manyena, S. B., E. Mavhura, C. Muzenda, and E. Mabaso. 2013. Disaster risk reduction legislations: Is there a move from events to processes? Global Environmental Change 23:1786-1794. https://doi.org/10.1016/j.gloenvcha.2013.07.027

McGee, T. K., and S. Russell. 2003. "It's just a natural way of life..." an investigation of wildfire preparedness in rural Australia. Global Environmental Change Part B: Environmental Hazards 5:1-12. https://doi.org/10.1016/j.hazards.2003.04.001

McLennan, B., J. Whittaker, and J. Handmer. 2016. The changing landscape of disaster volunteering: opportunities, responses and gaps in Australia. Natural Hazards 84:2031-2048. https://doi. org/10.1007/s11069-016-2532-5

McLennan, B., J. Whittaker, T. Kruger, and J. Handmer. 2020. Navigating authority and legitimacy when 'outsider' volunteers co-produce emergency management services. Environmental Hazards 20:7-22. https://doi.org/10.1080/17477891.2020.1727829

McLennan, J., and A. Birch. 2005. A potential crisis in wildfire emergency response capability? Australia's volunteer firefighters. Global Environmental Change Part B: Environmental Hazards 6:101-107. https://doi.org/10.1016/j.hazards.2005.10.003

McWethy, D. B., T. Schoennagel, P. E. Higuera, M. Krawchuk, B. J. Harvey, E. C. Metcalf, C. Schultz, C. Miller, A. L. Metcalf, B. Buma, A. Virapongse, J. C. Kulig, R. C. Stedman, Z. Ratajczak, C. R. Nelson, and C. Kolden. 2019. Rethinking resilience to wildfire. Nature Sustainability 2:797-804. https://doi.org/10.1038/ $\underline{\text { S41893-019-0353-8 }}$

Midgley, G., and R. Rajagopalan. 2020. Critical systems thinking, systemic intervention, and beyond. Pages 1-51 in G. S. Metcalf, K. Kijima, and H. Deguchi, editors. Handbook of systems sciences. Springer Singapore, Singapore. https://doi. org/10.1007/978-981-13-0370-8 7-1

Milkoreit, M., M.-L. Moore, M. Schoon, and C. L. Meek. 2015. Resilience scientists as change-makers-growing the middle ground between science and advocacy? Environmental Science \& Policy 53:87-95. https://doi.org/10.1016/j.envsci.2014.08.003

Miller, S. 2020. Greenspace volunteering post-disaster: exploration of themes in motivation, barriers, and benefits from post-hurricane park and garden volunteers. Journal of Environmental Planning and Management 63:2004-2021. https:// doi.org/10.1080/09640568.2019.1700942

Ministry of Civil Defence and Emergency Management (MCDEM). 2019. National Disaster Resilience Strategy. MCDEM, Wellington, New Zealand.

Moritz, M. A., E. Batllori, R. A. Bradstock, M. A. Gill, J. Handmer, P. F. Hessburg, J. Leonard, S. McCaffrey, D. C. Odion, T. Schoennagel, and A. D. Syphard. 2014. Learning to coexist with wildfire. Nature 515:58-66. https://doi.org/10.1038/ nature 13946

Morrow-Howell, N., G. O'Neill, and J. Greenfield. 2011. Civic engagement: policies and programs to support a resilient aging society. Pages 147-162 in B. Resnick, L. P. Gwyther, K. A. Roberto, editors. Resilience in aging: concepts, research, and outcomes. Springer, Cham, Switzerland. https://doi.org/10.1007/978-1-4419-0232-0 10

Mulligan, M., W. Steele, L. Rickards, and H. Fünfgeld. 2016. Keywords in planning: what do we mean by 'community resilience'? International Planning Studies 21:348-361. https:// doi.org/10.1080/13563475.2016.1155974

Mutu, M. 2019. 'To honour the treaty, we must first settle colonisation' (Moana Jackson 2015): the long road from colonial devastation to balance, peace and harmony. Journal of the Royal Society of New Zealand 49:4-18. https://doi.org/10.1080/03036758.2019.1669670

National Emergency Management Agency. 2019. National disaster resilience strategy. Ministry for Civil Defence and Emergency Management, Wellington, New Zealand. [online] URL: https://www.civildefence.govt.nz/cdem-sector/plans-andstrategies/national-disaster-resilience-strategy/

New Zealand Forest Owners Association (NZFOA). 2018. Forest fire risk management guidelines. NZFOA, Wellington, New Zealand.

New Zealand Treasury (NZT). 2016. New Zealand Economic and Financial Overview 2016. NZT, Wellington, New Zealand.

Paton, D., P. T. Buergelt, F. Tedim, and S. McCaffrey. 2015. Chapter 1 - Wildfires: international perspectives on their socialecological implications. Pages 1-14 in J. F. Shroder and D. Paton, editors. Wildfire hazards, risks and disasters. Elsevier, Oxford, UK. https://doi.org/10.1016/b978-0-12-410434-1.00001-4

Paveglio, T. B., M. S. Carroll, and P. J. Jakes. 2010. Alternatives to evacuation during wildland fire: exploring adaptive capacity in one Idaho community. Environmental Hazards 9:379-394. https://doi.org/10.3763/ehaz.2010.0060

Pearce, H., G. Cameron, S. Anderson, and M. Dudfield. 2008. An overview of fire management in New Zealand forestry. New Zealand Journal of Forestry 53:7-11.

Pearce, H. G. 2018. The 2017 Port Hills wildfires - a window into New Zealand's fire future? Australasian Journal of Disaster and Trauma Studies: Port Hills Wildfire Special Issue 22:35-50.

Potter, S. H., J. S. Becker, D. M. Johnston, and K. P. Rossiter. 2015. An overview of the impacts of the 2010-2011 Canterbury 
earthquakes. International Journal of Disaster Risk Reduction 14:6-14. https://doi.org/10.1016/j.ijdrr.2015.01.014

Prior, T., and C. Eriksen. 2013. Wildfire preparedness, community cohesion and social-ecological systems. Global Environmental Change 23:1575-1586. https://doi.org/10.1016/j.gloenvcha.2013.09.016

RadioNZ. 2019. Wakefield evacuees allowed to return to their homes. RNZ, Wellington, New Zealand.

Rast, M. C., Y. Younes, P. Smets, and H. Ghorashi. 2019. The resilience potential of different refugee reception approaches taken during the 'refugee crisis' in Amsterdam. Current Sociology 68:853-871. https://doi.org/10.1177/0011392119830759

Saaroni, L. 2015. Managing spontaneous volunteers in emergencies: a local government perspective. Australian Journal of Emergency Management 30:56-59.

Saunders, W. S. A., and J. S. Becker. 2015. A discussion of resilience and sustainability: land use planning recovery from the Canterbury earthquake sequence, New Zealand. International Journal of Disaster Risk Reduction 14:73-81. https://doi. org/10.1016/j.ijdrr.2015.01.013

Sharpe, B., A. Hodgson, G. Leicester, A. Lyon, and I. Fazey. 2016. Three horizons: a pathways practice for transformation. Ecology and Society 21(2):47. https://doi.org/10.5751/ES-08388-210247

Sinclair, K., A. Rawluk, S. Kumar, and A. Curtis. 2017. Ways forward for resilience thinking: lessons from the field for those exploring social-ecological systems in agriculture and natural resource management. Ecology and Society 22(4):21. https://doi. org/10.5751/ES-09705-220421

Skutsch, M., and E. Turnhout. 2018. How REDD+ is performing communities. Forests 9:638. https://doi.org/10.3390/f9100638

Smith, A. M. S., C. A. Kolden, T. B. Paveglio, M. A. Cochrane, D. M. J. S. Bowman, M. A. Moritz, A. D. Kliskey, L. Alessa, A. T. Hudak, C. M. Hoffman, J. A. Lutz, L. P. Queen, S. J. Goetz, P. E. Higuera, L. Boschetti, M. Flannigan, K. M. Yedinak, A. C. Watts, E. K. Strand, J. W. van Wagtendonk, J. W. Anderson, B. J. Stocks, and J. T. Abatzoglou. 2016. The science of firescapes: achieving fire-resilient communities. BioScience 66:130-146. https://doi.org/10.1093/biosci/biv182

Spector, S., N. Cradock-Henry, S. Beaven, and C. Orchiston. 2019. Characterising rural resilience in Aotearoa-New Zealand: a systematic review. Regional Environmental Change 19:543-557. https://doi.org/10.1007/s10113-018-1418-3

StatsNZ. 2018a. Renwick, population and dwellings, population counts. StatsNZ, Wellington, New Zealand.

StatsNZ. 2018b. Marlborough Region. Population and dwellings, Population counts. StatsNZ, Wellington, New Zealand.

StatsNZ. 2018c. Geographic boundary viewer. Marlborough District land area 10,457.82 Sq km. StatsNZ, Wellington, New Zealand.

Stephens, S. L., M. A. Adams, J. Handmer, F. R. Kearns, B. Leicester, J. Leonard, and M. A. Moritz. 2009. Urban-wildland fires: how California and other regions of the U.S. can learn from Australia. Environmental Research Letters 4:14010. https://doi. org/10.1088/1748-9326/4/1/014010
Stojanovic, T., H. McNae, P. Tett, T. W. Potts, J. Reis, H. D. Smith, and I. Dillingham. 2016. The "social" aspect of social-ecological systems: a critique of analytical frameworks and findings from a multisite study of coastal sustainability. Ecology and Society 21 (3):15. https://doi.org/10.5751/es-08633-210315

Tedim, F., V. Leone, and G. Xanthopoulos. 2016. A wildfire risk management concept based on a social-ecological approach in the European Union: Fire Smart Territory. International Journal of Disaster Risk Reduction 18:138-153. https://doi.org/10.1016/ j.ijdrr.2016.06.005

United Nations International Strategy for Disaster Risk Reduction (UNISDR). 2009. UNISDR terminology on disaster risk reduction. UNISDR, Geneva, Switzerland.

United Nations International Strategy for Disaster Risk Reduction (UNISDR). 2015. Sendai Framework for Disaster Risk Reduction 2015-2030. United Nations Office for Disaster Risk Reduction, Geneva, Switzerland.

Vallance, S. 2012. Urban resilience: bouncing back, coping and thriving. Earth: fire and rain: Australian \& New Zealand Disaster and Emergency Management Conference, Brisbane, Australia.

Vallance, S., and S. Carlton. 2015. First to respond, last to leave: communities' roles and resilience across the '4Rs'. International Journal of Disaster Risk Reduction 14:27-36. https://doi. org/10.1016/j.ijdrr.2014.10.010

Vickers, G. 1965. The art of judgment: a study of policy making. SAGE, London, UK.

Watt, M., M. Kirschbaum, J. Moore, H. Pearce, L. Bulman, E. Brockerhoff, and N. Melia. 2019. Assessment of multiple climate change effects on plantation forests in New Zealand. Forestry 92:1-15. https://doi.org/10.1093/forestry/cpy024

Werder, C., S. Thibou, S. Simkins, K. Hornsby, K. Legg, and T. Franklin. 2016. Co-inquiry with students: when shared questions lead the way. Teaching \& Learning Inquiry 4(2)21-35. https://doi. org/10.20343/teachlearninqu.4.2.4

Westley, F. R., O. Tjornbo, L. Schultz, P. Olsson, C. Folke, B. Crona, and Ö. Bodin. 2013. A theory of transformative agency in linked social-ecological systems. Ecology and Society 18(3):27. https://doi.org/10.5751/ES-05072-180327

Whittaker, J., B. McLennan, and J. Handmer. 2015. A review of informal volunteerism in emergencies and disasters: definition, opportunities and challenges. International Journal of Disaster Risk Reduction 13:358-368. https://doi.org/10.1016/j.ijdrr.2015.07.010

Wither, D., C. Orchiston, N. A. Cradock-Henry, and E. Nel. 2021. Advancing practical applications of resilience in Aotearoa-New Zealand. Ecology and Society 26(3):1. https://doi.org/10.5751/ ES-12409-260301

Wittmayer, J. M., N. Schäpke, F. van Steenbergen, and I. Omann. 2014. Making sense of sustainability transitions locally: how action research contributes to addressing societal challenges. Critical Policy Studies 8:465-485. https://doi.org/10.1080/19460$\underline{171.2014 .957336}$

Woodier, D. 2011. Building resilience in Looked After young people: a moral values approach. British Journal of Guidance \& Counselling 39:259-282. https://doi.org/10.1080/03069885.2011.562638 


\section{Appendix 1}

\section{Systemic co-inquiry}

An explanation of the lines of thinking behind the development of systemic co-inquiry as a methodology is given, starting with developing a systems view. Further explanation of method is attended by a description of systemic inquiry and cooperative inquiry as articulated by Ray Ison and John Heron respectively. Systemic co-inquiry as developed by Foster et al (2018) is summarised as well as our application of the method for the research addressed by this paper.

\section{Developing a systems view}

The International Society of Systems Science has a primer to introduce systems science with some basic tenets of systems theory possibly dating back to the 1970s (Banathy, 'A Taste of Systemics' n.d.), as:

- A systems view is a way of looking at the world from many perspectives

- A system can be viewed as a configuration of parts connected and joined together through a web of relationships

- A systems view is one of how things are working together and thus enables viewers to see the effect of different parts working as a whole

- The joining and integrating of a web of relationships creates emergent properties

- Because these properties are the result of relationships they will not be found in any analysis of the parts or from a single viewpoint

The value of systems theory is that wholeness cannot be seen in the parts that make up the system and therefore requires a multi-perspective view to grasp and show the effect of interacting parts.

According to Banathy systems inquiry is a research model (paradigm ${ }^{1}$ ) of how things work together to attain wholeness. When taken as a whole, systems inquiry is a prescription for action - it both produces systems knowledge and applies systems knowledge to address real world situations. The aim is to effect change (e.g., in understanding and practice) that results in improved performance of systems and ongoing learning of those involved in the systems inquiry.

Systems inquiry offers a view into living reality as opposed to abstracted reality where parts are extracted from and analysed separately from real world interactions.

Systems methodology is different from disciplinary methodology in that one selects methods and tools - from a wide range of approaches - that best fit the type of system (as it is perceived), the purpose and nature of inquiry and the specific problem situation.

According to Ray Ison (Pers. Comm.), one has to be aware of the tensions within the Systems community between those who hold - knowingly or not - a commitment to seeing systems as ontologies - things in the world OR to systems as epistemologies brought forth by concerned practitioners/scholars as epistemological devices for knowing about or changing situations systemically or systematically ${ }^{2}$.

\footnotetext{
${ }^{1}$ Kuhn (1996/1970) defines a scientific paradigm as: "universally recognized scientific achievements that, for a time, provide model problems and solutions for a community of practitioners"

2 Ison (2010, Ch2) outlines systemic and systematic as disciplinary differences between systemically looking at a situation as a whole and systematic methodologies of examining them. These are both used in systems science and systemic thinking in practice.
} 
Understanding context is a key element of systems inquiry where the problem focus can be understood from diverse perspectives acting within or having an effect in that context.

Reflecting from its development as at the late 1970s Banathy characterised systems methodology as having two domains of inquiry; i) the study of methods by which we pursue systems scholarship and produce systems knowledge (how we know about systems), and ii) the identification and descriptions of methods and tools for applying systems theory and system thinking in analytical practice (how we use systems thinking to support practical action).

However, Ison and colleagues have shifted this thinking towards an understanding of how we carry traditions of understanding into our methodological practices. Therefore, our frames and framework of ideas inform how we view the world in 'systems'. This is often transferred via an ontological trick of assuming the world exists outside of our frameworks exactly in the way we have conceptualised.

All knowing and knowledge practices are embedded within human orientations and development of tools for interrogating the world and relationships within it. Ison's (2017) work sets out to understand practice, especially research practice and what makes research practice systems research practice.

\section{Understanding practice...?}
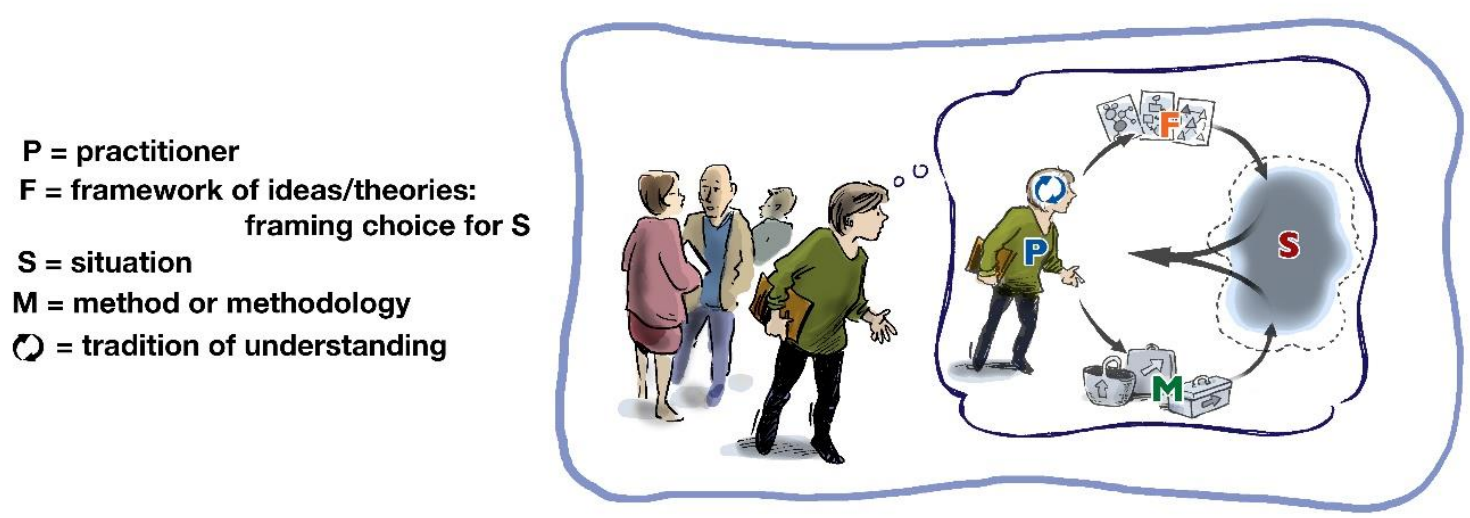

Fig A1-1: An heuristic for understanding the systemic dynamics of reflexive, research praxis: as a set of relational dynamics involving a practitioner $(P)$ with a tradition of understanding and framework of ideas $(F)$, and theories framing choice for a situation $(S)$ and a method or methodology for inquiry. Understood as a system, complexity is added as research is done with others thus justifying coinquiry (Ison and Straw 2020).

Ison (Pers. Comm.) notes that bringing systems practice to bear through systemic inquiry or coinquiry involves being:

- open to a situation and our agency in making framing choices for the situation - including as a system

- alert to the need to gain and involve others who collectively offer multiple partial perspectives of a situation of concern

- aware of when it is desirable to engage with a situation systemically and/or systematically (appreciating initial starting conditions) 
- able to identify, characterise and classify elements in the situation that can influence formulation (including boundary choices) of a system of our interest and thus what is perceived to be in the environment of the system we have formulated as an epistemological device (this process can be repeated as a means of learning about a situation systemically and becoming equipped to judge what changes may be systemically desirable and culturally feasible). The concept system carries with it an appreciation that systems can comprise a layered structure (meta-system, system and sub-system) and that there will be emergent properties apparent at different levels that are not predictable from knowing the parts at the lower layer

- equipped to select, identify and characterise specific strategies, methods and tools appropriate to work based on the learning (and possibly implementation) of our particular system of interest

Practices are methodologically tied to our framing choices including epistemic choices of problems and ways of understanding them. We cannot know them to exist independently of our construction of them. The more closely we work with others, the more the shape of systems inquiry melds with their experience and can help to create awareness of what effect they/we are having in the world. Creatively building systems-of-interest from an awareness of when to be able to think and act systemically and/or systematically is central to systems practice of all forms. For a system to be fully comprehended it must include the observer as part of the system, thus entailing the social relations within which the observer sits. Therefore, systemic inquiry acknowledges there is no real objectivity as we are all embedded in social relations that shape the questions we ask and the observations made.

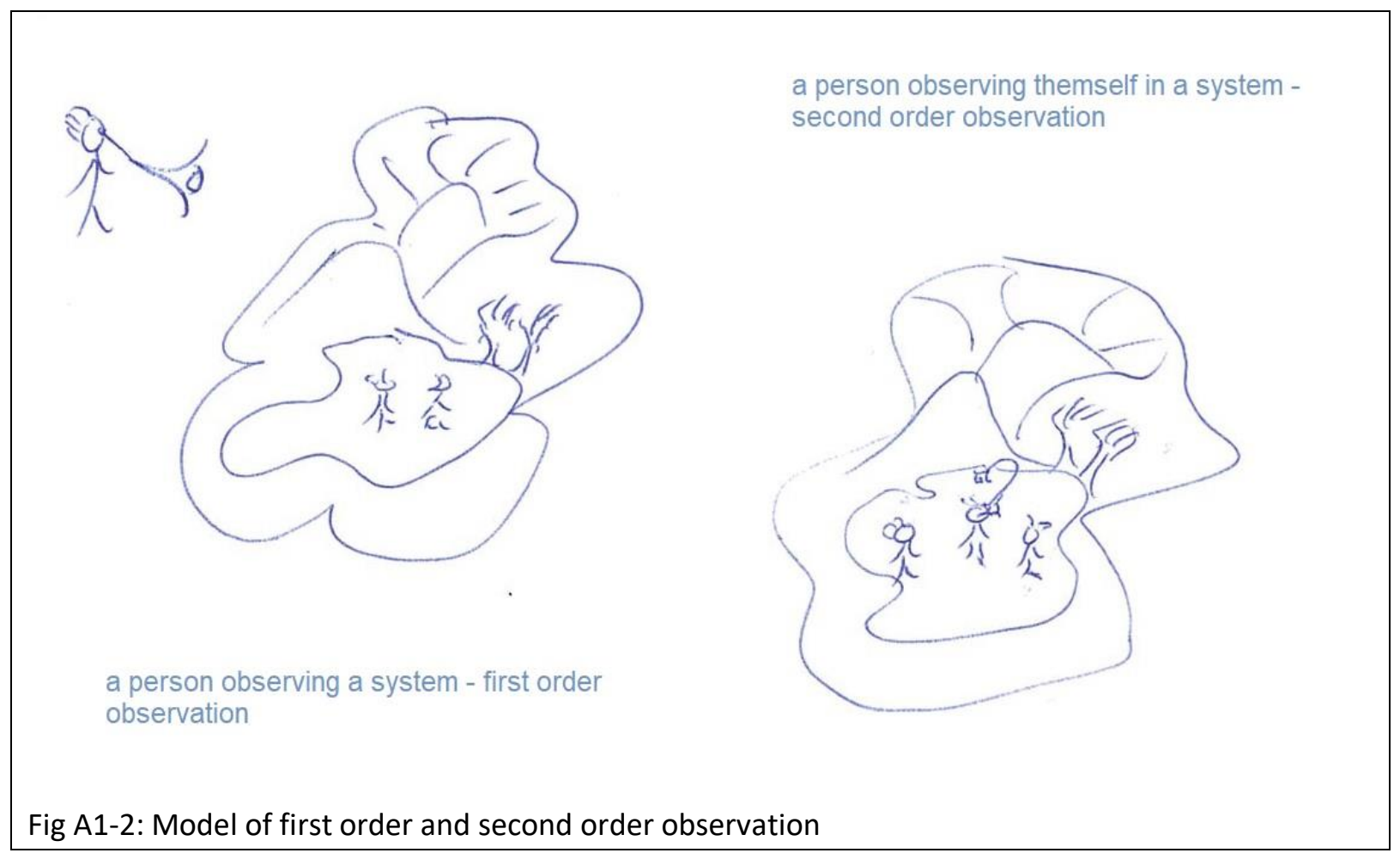

\section{Systemic inquiry}


The process of systemic inquiry is enacted as a learning process between those who have a stake in a situation of concern (something problematic about what they are experiencing) that presents an opportunity for change. Designing a systemic inquiry is open to anyone who can make a connection between a theoretical framework, a methodological approach and a given situation (Ison 2010). Systemic inquiry does not happen in the abstract as such but happens through an interaction between abstract thought and actual practice, in the real world.

It is therefore not reductionist but systemic and embracing of different things happening in different parts of the system, including how they are perceived by practitioners.

\section{Systemic inquiry for handling complexity and uncertainty}

Ison (2010) in his book 'How to live in a climate change world?', argues the case for systemic inquiry as a social technology, or form of, for dealing with complex societal or ecological problems involving uncertainty and requiring adaptation. He describes systemic inquiry as a "meta-platform for project or programme managing" that can be used in a way that facilitates "social learning or concerted action ... toward better understanding" (p. 236). Further visualisation and valuation of systemic inquiry is provided through worked examples by Ison (2010, pp. 168, 172, Table 7.3).

With respect to seeing problems from multiple partial perspectives (as outlined above by Banathy), Ison explains:

\footnotetext{
"Within systems practice in general, and systemic inquiry in particular, the surfacing and valuing of multiple partial perspectives is an important means to address the question of what constitutes change for the better. There is never one single right answer or perspective in relation to complex and uncertain issues. Hence processes of decision making that employ and value different perspectives are likely to lead to decisions that are more robust and fit for purpose." (p. 231)
}

Following Ison, (2010, p. 239), there is no definitive way of setting up a systemic inquiry or of enacting one. In addition to ongoing involvement, capabilities are required for: understanding context; appreciating multiple viewpoints; addressing and clarifying purpose; distinguishing what, how and why; facilitating action that is purposeful (i.e., systemically desirable and culturally feasible); and institutionalising ongoing use of the approach and its outcomes.

Moreover, systemic inquiry is an approach to practice drawing explicitly from systems thinking/ science, theories of learning, action research, cooperative inquiry and adaptive management (Ison 2010, p. 240). Changes arising from enacting systemic inquiry are manifest as changes in understanding and practice, changes in social relations amongst those involved, and changes in process or changes in structure (p. 241). Clearly the need for time to establish these relationships and work in a systemic way is important, and this is often not possible within the 1-5 year cycles of research funding.

\section{Cooperative inquiry}

For Heron (1996) the originator of the research method, Cooperative Inquiry requires two or more people researching a topic through their own experience and going through cycles of experience and reflecting together. During the experiencing phases, each person is a co-subject and during reflection they are a co-researcher. Like Ison's explication of systemic inquiry (2010, p. 239), this model of research has affinity with other research models including action research and experiential learning, in this case founded in the theoretical developments of Kurt Lewin (1952). Heron, takes these concepts further into practical contexts where persons involved in reciprocal relations of inquiry use a fuller range of sensibilities into understanding their topic. Drawing on the metaphor of 
the 'gaze' Heron suggests a deeper engagement with a topic than eyes on physical objects, combining spatial and mental properties of mind, involving participatory non-inferential but partial knowledge of the state of mind of the other. An inherent mutuality of meaning is presupposed and grounded by the use of speech (Heron 1996, p.1) or dialogic engagement of co-inquirers with the topic for discussing and sharing interpretation. Reason (1998), also sought to see the relationship of research from external observation to engaged co-inquiry with people impacted by a topic of interest. Reason notes that he could not adequately research people from outside of their context and needed to engage with ways of knowing through epistemological, political, ecological and spiritual dimensions of participatory research.

\section{Systemic co-inquiry}

\section{Combining co-inquiry with systemic inquiry}

Foster et al (2018) draw from Heron and Reason (2001) in arguing that participants in a co-inquiry need to be involved as co-researchers and can contribute to the design, implementation, monitoring and evaluation of the research. Systemic co-inquiry draws on systems theory, methodologies and techniques, such as those proposed by Dewey as methods of inquiry into problematic situations (e.g., Schön 1996), developing appreciative systems (e.g., Vickers 1965), and recognising many possible worldviews and perspectives (e.g., Churchman 1971) (Ison 2010, p. 237). Systemic coinquiry is a mode of investigation or research that is open to changing situations, pursing new directions, as a result of learning and testing new areas of understanding. It can lead to engaging with new theoretical and methodological frameworks that come out of shared or joint learning experiences and appreciating other people's perspectives (Foster et al 2018, p. 10).

Foster et al (2016) note that

“... systemic co-inquiries proceed by enacting a social learning process with those who have a stake in a situation experienced as problematic or as presenting an opportunity. Thereby, they enable participants to begin their investigations in a different emotional space to that which accompanies the emotion of certainty usually associated with programmes and projects." (p.16)

A systemic co-inquiry adds the tools and methods of systems thinking to complement the basis of meaning in language and speech framed by co-inquiry to include visualisations of a systemic nature. Beyond conventions of social science, Heron (1996) proposed that doing experiments on and gathering data from other people does not adequately inquire into the nature of the human condition. It requires that the researcher also become a "socially sensitive subject involved in mutual gazing with another" (p.1). There are clear symmetries between Heron's thinking of the human condition and Ison's development of systems practice as inquiry into human activity systems. Second order observations of a person as an inquirer in an inquiry system, pulls away from the social science convention of first order observation from outside of a system of interest (see Figure A1-2).

\section{The approach used in our paper}

In our case we allowed our systemic and cooperative inquiries to overlap. However, we started the co-inquiry process reported in this paper by working with our key participants. The cooperative inquiry was a result of a first person systemic inquiry (of the first author reflecting on the need to embed research practice within the worlds of practitioners). We then sought out people who could be worked with, during the process of being shown around the research field through the second authors contacts. Additional networks were created as a result of adapting research to the needs of a dynamic or changing setting, including: creation of FENZ from 41 separate fire brigade/ service organisation; and a major earthquake event during the research period. As the first author met 
people in the New Zealand context of wildfire and hazards research and response practice, questions were raised about preparedness and practitioners who were proactive in that space were brought into more focussed discussions. Originally tasked with the challenge of research responding to the question of how to bring those outside of the traditions of rural fire volunteers (e.g., women, youth and elders) into the fire services for building community resilience, we adapted our research question to suit the context and other global developments in research and practice around bringing informal and formal volunteers together to build resilience to natural hazards. The research reported here bodes the beginning of a systemic co-inquiry, in which participants are brought into a context through which they may collectively work towards an unfolding awareness and understanding of community wildfire (as one of many rural community hazards) resilience.

\section{References}

Banathy, B. (n.d.) 'A Taste of Systemics', 'Why a Systems View?', 'Systems Inquiry' Available online, accessed 17 March 2017 https://web3.isss.org/primer2/asem04bb.html

Churchman, C. W. (1971). The Design of Inquiring Systems: basic concepts of systems and organizations, New York, Basic Books.

Foster, N., Ison, R., Blackmore, C., and Collins, K. (2018) Partnerships for action in river catchment governance: A case study in the Irwell UK. The Open University, Milton Keynes, UK.

Heron, J. (1996) Cooperative Inquiry. Sage, Thousand Oaks, London.

Heron, J., and Reason, P. (2001). The practice of co-operative inquiry: Research "with" rather than "on" people. In Reason, P., and Bradbury, H. (eds.), Handbook of Action Research, first edition, London, Sage, pp 179-188

Ison, R. (2010) 'Systems Practice: How to Act in a Climate Change World. Springer

Ison, R. (2017) Systems Practice: How to Act: In situations of uncertainty and complexity in a climatechange world. Springer

Ison, R and Straw, E. (2020) The Hidden Power of Systems Thinking. Routledge

Kuhn, TS. (1996/1970) The Structure of Scientific Revolutions, 3rd edition. Chicago: University of Chicago Press, p10

Lewin, K. (1952) Field Theory in Social Science. In Dorwin Cartwright (Ed) Social Science Paperbacks. London, Tavistock Publications

Reason, P. (1998) Political Epistemological, Ecological and Spiritual Dimensions of Participation. Studies in Culture, Organizations and Societies, 4, 147-167

Schön, D.A. (1995). The new scholarship requires a new epistemology. Change November/ December, 27-34.

Vickers, G. (1965). The Art of Judgement: a study of policy making. London: Chapman and Hall. 